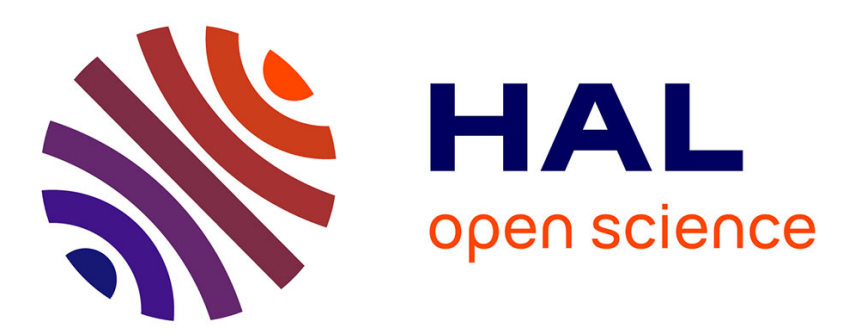

\title{
Correlation Between Microstructure and Na Storage Behavior in Hard Carbon
}

Biao Zhang, Camélia Matei Ghimbeu, Christel Laberty, Cathie Vix-Guterl, Jean-marie Tarascon

\section{- To cite this version:}

Biao Zhang, Camélia Matei Ghimbeu, Christel Laberty, Cathie Vix-Guterl, Jean-marie Tarascon. Correlation Between Microstructure and Na Storage Behavior in Hard Carbon. Advanced Energy Materials, 2016, 6 (1), pp.1501588. 10.1002/aenm.201501588 . hal-02465142

\section{HAL Id: hal-02465142 \\ https://hal.science/hal-02465142}

Submitted on 7 Feb 2020

HAL is a multi-disciplinary open access archive for the deposit and dissemination of scientific research documents, whether they are published or not. The documents may come from teaching and research institutions in France or abroad, or from public or private research centers.
L'archive ouverte pluridisciplinaire $\mathbf{H A L}$, est destinée au dépôt et à la diffusion de documents scientifiques de niveau recherche, publiés ou non, émanant des établissements d'enseignement et de recherche français ou étrangers, des laboratoires publics ou privés. 
Correlation between microstructure and $\mathrm{Na}$ storage behavior in hard carbon

Biao Zhang, Camélia Matei Ghimbeu, Christel Laberty, Cathie Vix-Guterl and Jean-Marie Tarascon*

Dr. B. Zhang, Prof. J.M. Tarascon

FRE 3677 "Chimie du Solide et Energie", Collège de France, 11 Place Marcelin Berthelot, 75231 Paris Cedex 05, France.

Email: jean-marie.tarascon@ college-de-france.fr

Dr. C. Matei Ghimbeu, Dr. C. Vix-Guterl

Institut de Science des Matériaux de Mulhouse (IS2M) - CNRS UMR 7361, France

Prof. C. Laberty

LCMCP, Université de Jussieu 75005, Paris, France

Dr. B. Zhang, Dr. C.Matei Ghimbeu, Prof. C. Laberty, Dr. C. Vix-Guterl, Prof. J.M. Tarascon Réseau sur le Stockage Electrochimique de l'Energie (RS2E), FR CNRS 3459, France

Keywords: Na-ion battery, hard carbon, carbon nanofiber, microstructure

\begin{abstract}
Hard carbons are considered among the most promising anode materials for Na-ion batteries. Understanding their Na storage capabilities is of great importance for optimizing their structure and therefore achieving high performance. Herein carbon nanofibers (CNFs) were prepared by electrospinning and their microstructure, texture and surface functionality were tailored through carbonization at various temperatures ranging from 650 to $2800^{\circ} \mathrm{C}$. Stepwise carbonization gradually removes the heteroatoms and increases the graphitization degree, enabling us to monitor the corresponding electrochemical performance for establishing a correlation between the CNFs characteristics and $\mathrm{Na}$ storage behavior in hard carbons. Outstandingly, we found for CNFs carbonized above $2000{ }^{\circ} \mathrm{C}$, a single voltage Na uptake plateau at $\sim 0.1 \mathrm{~V}$ with a capacity of $\sim 200 \mathrm{mAh} / \mathrm{g}$. This specific performance may be nested in the higher degree of graphitization, lower active surface area (ASA) and different porous texture of the CNFs at such temperatures. We demonstrate via the assembly of a full $\mathrm{CNF} / \mathrm{Na}_{2} \mathrm{Fe}\left(\mathrm{SO}_{4}\right)_{3}$ cell the benefit of such $\mathrm{CNF}$ s electrode for enhancing the energy density of
\end{abstract}


full Na-ion cells. This finding sheds new insights in the quest for high performance carbon based anode materials.

\section{Introduction}

The revival of Na-ion batteries rely on the low cost and widely availability of sodium sources with the possibility of developing high performance, low cost electrode materials ${ }^{[1,2]}$. High capacity $\mathrm{P} 2$-type $\mathrm{Na}_{0.67}\left[\mathrm{Fe}_{0.5} \mathrm{Mn}_{0.5}\right] \mathrm{O}_{2}{ }^{[3]}$ and high voltage polyanionic $\mathrm{Na}_{2} \mathrm{~V}_{2}\left(\mathrm{PO}_{4}\right)_{2} \mathrm{~F}_{3}{ }^{[4]}$ have been widely studied as potential cathodes, delivering comparable energy density with Li-ion batteries. Current anodes are based on the similar materials as that for Li-ion batteries, including carbon, alloys and metal oxides ${ }^{[5]}$. However, Carbon have emerged as one of the most promising classes of materials in the searching of anodes, although widely used graphite cannot be blindly implemented with carbonate electrolyte ${ }^{[6]}$. Only solvated $\mathrm{Na}$ ions could be intercalated into graphite when appropriate electrolyte, such as ether-based electrolyte, [xxx] is used. Therefore, other forms of carbon, such as hard carbon ${ }^{[7]}$ and graphene ${ }^{[8]}$, have been widely studied. A decent capacity of $\sim 200 \mathrm{mAh} / \mathrm{g}$ could be obtained so that C-based Na-ion cells were assembled and tested ${ }^{[9]}$.

Hard carbon materials that contain randomly oriented graphene layers are the most studied candidate anodes. They are usually prepared by pyrolysis of organic and polymer precursors, such as glucose $\mathrm{e}^{[7]}$, sugar ${ }^{[10]}$ and polypyrrole ${ }^{[11]}$, at around $1000^{\circ} \mathrm{C}$. Due to the presence of large amount of $\mathrm{sp}^{3}$ structure in the precursor, parallel growth of graphene layers is somewhat inhibited, giving rise to plenty of defects. Like Li ion storage in carbons, $\mathrm{Na}$ ions can equally be stored in carbons via i) adsorption on the surface and defects, ii) nanopore filling and iii) intercalation between the graphene layers of large d-spacing. Although a number of studies have been conducted on the hard carbon anode, there are numerous discrepancies concerning the $\mathrm{Na}$ ion storage mechanisms as a diversity of both voltage profiles and capacities are reported. The charge/discharge curves of hard carbon normally consist of two regions: i) a 
slope between $1.0-0.1 \mathrm{~V}$ and ii) one flat plateau at $\sim 0.1 \mathrm{~V}$. The first one has been explained by either $\mathrm{Na}$ insertion into nearly parallel graphene layers ${ }^{[12]}$ or binding of $\mathrm{Na}$ at vacancies ${ }^{[13]}$. Equally, there is no consensus regarding the assignment of the flat plateau which is presented as due either to the $\mathrm{Na}$ intercalation between expanded graphene layers ${ }^{[14]}$ or to nanopore filling/nanoplating ${ }^{[7]}{ }^{[12]}$. Obviously these different assignments come from the variation in the microstructure/texture which depends on both the carbon precursor and thermal annealing processes. Moreover, the high capacity at above $1 \mathrm{~V}$ is also assigned to heteroatom doping ${ }^{[15]}$, hence calling for a careful examination on the effect of functional groups containing $\mathrm{N}$ and $\mathrm{O}$ atoms. Systematic studies on tailoring the microstructure and chemical composition of hard carbon are therefore required in order to establish a possible relationship between heteroatoms, microstructure, texture and electrochemical properties vs $\mathrm{Na}^{+} / \mathrm{Na}^{0}$.

Carbon nanofibers (CNFs) prepared by electrospinning have been extensively studied in Liion batteries, serving as both anode materials and substrates for supporting metal oxides ${ }^{[16,17]}$. Recent studies on neat CNFs and their hybrids with Sb suggests that they can also be employed in Na-ion batteries ${ }^{[18,19]}$. Although CNFs have generally a lower density than graphite, a side advantage if that they can be made in flexible thin film forms to be used for wearable electronics $^{[20]}$. Because of the high carbon yield, low cost and easy spinnability, polyacrylonitrile (PAN) is considered among the most suitable polymer precursors to produce $\mathrm{CNFs}^{[21]}$.

Therefore, in this work self-sustained PAN derived CNF films by stepwise carbonization/graphitization were used for the understanding of $\mathrm{Na}$ ion storage mechanism. Gradually heating of PAN fibers between $650^{\circ} \mathrm{C}$ and $2800^{\circ} \mathrm{C}$ allowed to obtain several materials having distinct surface functionalities, textures, structures and reactivity as highlighted by systematic analysis using a large panel of techniques. Three domains of $\mathrm{Na}$ storage mechanism were identified based on the CNFs features induced by temperature interval 
used for the carbonization/graphitization and the Na ion storage behavior. Importantly, a single voltage Na plateau at $\sim 0.1 \mathrm{~V}$ with a capacity of $\sim 200 \mathrm{mAh} / \mathrm{g}$ is for the first time observed for high temperature treated CNFs $\left(>2000{ }^{\circ} \mathrm{C}\right)$. Full cell based on such CNFs and $\mathrm{Na}_{2} \mathrm{Fe}_{2}\left(\mathrm{SO}_{4}\right)_{3}$ was demonstrated to provide improved energy density for Na-ion full cells.

\section{Results and Discussions}

Scanning Electron Microscopy (SEM) images of PAN fibers in Figure S1a,b show a fine one-dimensional structure with fibers having diameters ranging from 100 to $300 \mathrm{~nm}$ and little amount of beads. This structure is well maintained during stabilization and carbonization, giving rise to uniform CNFs having slightly smaller average diameters (150 nm vs. $200 \mathrm{~nm})$ and a more dense appearance than PAN fibers (Figure S1c,d). The carbon yield (i.e., the mass ratio of obtained CNFs to PAN) significantly decreases from $67 \%$ to $42 \%$ with increasing temperature between 650 and $950^{\circ} \mathrm{C}$, respectively (Figure S2). No significant difference in the carbon yield is noticed for temperatures higher than $950^{\circ} \mathrm{C}$. Several complementary analysis techniques were employed to determine the composition and surface functionalities of CNFs at different stages of carbonization/graphitization process. These functionalities, which are known to strongly modify the electronic and the wettability properties of the materials ${ }^{[22]}$ may play a key role in the interactions with the electrolyte and consequently impact the Na storage performances.

The elemental analysis and X-ray photoelectron spectroscopy (XPS) (Figure 1a) show an increase in carbon content and a decrease in the heteroatoms, i.e., nitrogen and oxygen amount with increasing temperature, especially between 650 and $950^{\circ} \mathrm{C}$. In this region, it can be noticed as well that the oxygen content obtained from chemical analysis is higher than from the one deduced by XPS. Although this difference is nested in the fact that XPS is a surface technique probing solely $\sim 10 \mathrm{~nm}$ of carbon surface, as compared to elemental analysis which probes the whole sample, it indicates an oxygen gradient concentration between the core and 
surface of the sample. Thus the need to increase the treatment temperature to fully carbonize PAN is evident, as confirmed by the homogenous $\mathrm{O}$ and $\mathrm{N}$ content for samples treated at $\mathrm{T}>$ $1000^{\circ} \mathrm{C}$

Details about the types and evolution of $\mathrm{N}$ and $\mathrm{O}$ functional groups with the annealing temperature, as determined by deconvolution of the $\mathrm{C} 1 \mathrm{~s}, \mathrm{~N} 1 \mathrm{~s}$ and $\mathrm{O} 1 \mathrm{~s}$ XPS peaks are presented in Figure $1 \mathrm{~b}$ and Figure S3. The main nitrogen groups are the pyridine, pyridine pyrolic and quaternary $\mathrm{N}$ while for $\mathrm{O}$ mainly carbonyl $(\mathrm{C}=\mathrm{O})$, anhydrides $(\mathrm{O}=\mathrm{C}-\mathrm{O})$ and ether $(\mathrm{C}-\mathrm{OR})$ groups are observed. Both XPS and elemental analysis show that removal of $\mathrm{N}$ and $\mathrm{O}$ functional groups is the main reaction occurring below $1000^{\circ} \mathrm{C}$ (Figure 1a and Figure S3), explaining the observed decrease of carbon yield (Figure S2). The elimination of functional groups was in-situ monitored by temperature-programmed desorption coupled with mass spectrometry (TPD-MS). Figure 1c depicts the evolution of evolved gases during the TPD-MS experiment under vacuum for different thermal annealed CNFs. The basic and acidic oxygen functionalities are decomposed into $\mathrm{CO}$ and $\mathrm{CO}_{2}$, respectively ${ }^{[23,24]}$. It can be seen that for all materials the $\mathrm{CO}$ quantity is predominant, indicative of the presence of basic rather than acidic groups, in good agreement with the XPS results. Concomitant with the $\mathrm{CO}_{x}$ evolution, the desorption of $\mathrm{HCN}$ was observed due to the decomposition of nitrogen functional groups (data not shown). The precise quantity cannot be determined since no calibration with such species was performed. Besides $\mathrm{CO}_{x}$ and $\mathrm{HCN}$, water and $\mathrm{H}_{2}$ is evolved. The water is usually physisorbed/chemisorbed on carbon or in-situ formed by decomposition of neighbor oxygen groups. The $\mathrm{H}_{2}$ evolution is mainly attributed to $\mathrm{C}-\mathrm{H}$ bond cleavage ${ }^{[25]}$ indicating carbonization of the fibers. As expected, all these groups are evolved in higher quantities at low temperature.

Once these groups removed, the materials were further subjected to oxygen chemisorption and TPD-MS analysis to determine the active surface area (ASA). We have previously shown for graphite materials that the ASA influences the formation of SEI, the 
irreversible capacity loss in the first cycle and therefore the overall Li-ion battery performance. ${ }^{[25,26]}$ However, studies about the active surface area determination for hard carbons and its impact on Na storage mechanism were never reported. Figure 1d shows the evolution of ASA for several CNFs heated at temperatures higher than $950^{\circ} \mathrm{C}$ (temperature where the most surface groups is removed). The ASA sharply decreases from 23 to 1.1 when increasing the annealing temperature between 950 and $1250^{\circ} \mathrm{C}$. These values are very high indicating poorly organized and defective CNFs materials. For temperatures superior to $1250^{\circ} \mathrm{C}$, the ASA slightly decreases with the temperature down to 0.36 for $2800^{\circ} \mathrm{C}$ treated material; a value comparable to what was obtained with some graphite materials ${ }^{[26]}$.To grasp further insights into the parameters (degree of graphitization, type of defects... ) parameters, Transmission Electron Microscopy (TEM), X-ray diffraction (XRD) and Raman spectroscopy were performed. 

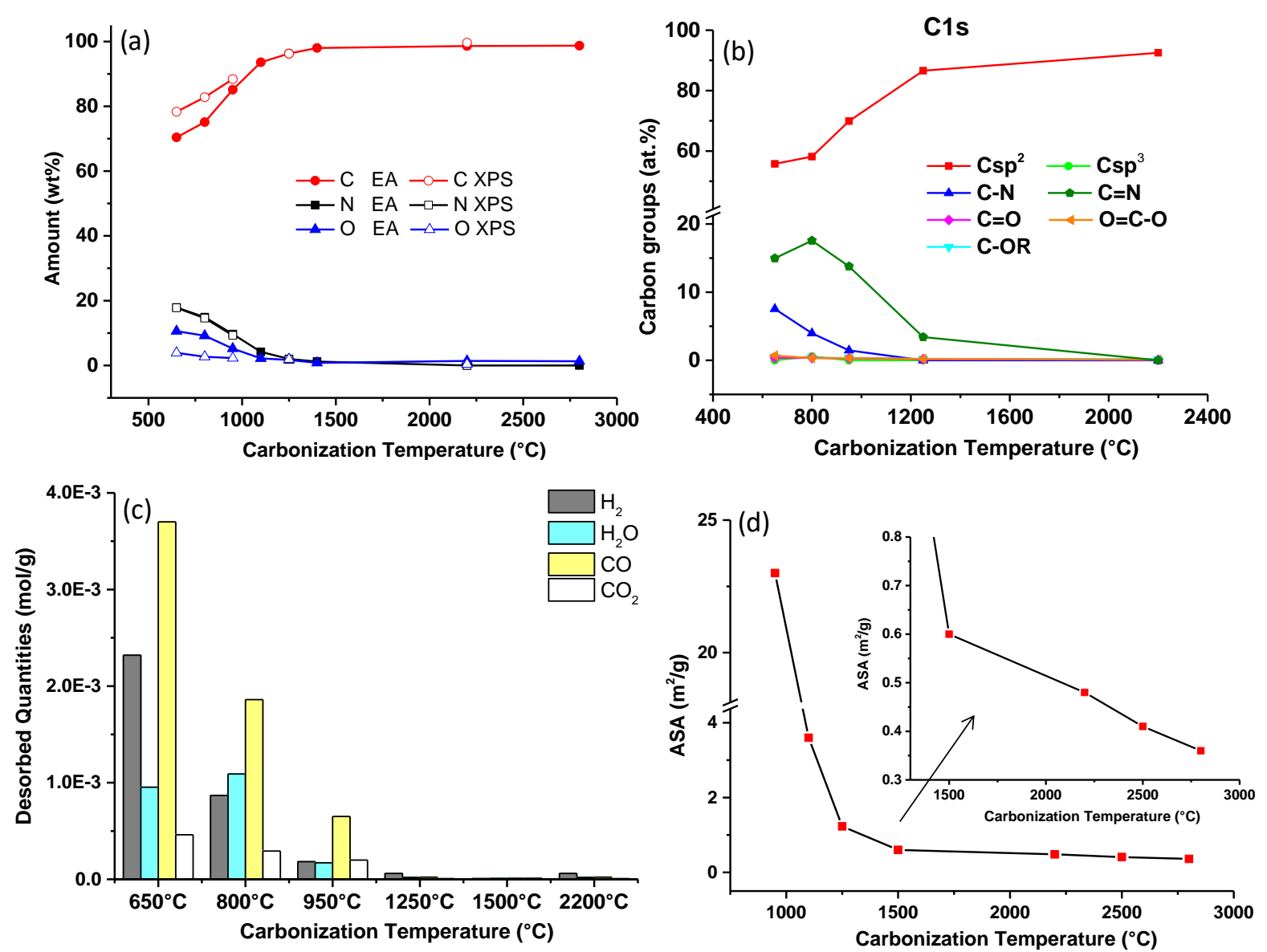

Figure 1 (a) composition by elemental analysis (EA) and XPS; (b) deconvoluted evolution of functional groups of C1s XPS spectra with the carbonization temperature of CNF for CNF earbenized bentities of $\mathrm{H}_{2}, \mathrm{H}_{2} \mathrm{O}, \mathrm{CO}$ and $\mathrm{CO}_{2}$ gases from CNF surface during TPD-MS analysis and (d) the active surface areas.

TEM pictures CNFs treated below $1000^{\circ} \mathrm{C}$ (Figure 2a-c) show disordered structure without clear evidence for graphene layers, most likely due to the lack of sufficient energy to drive the growth of such graphitic structure. In contrast, $\sim 10 \mathrm{~nm}$ islands of curved graphene layers with random orientation are observed for samples treated at above $1000^{\circ} \mathrm{C}$ (Figure $2 \mathrm{c}$ e); somewhat similar to the "card house" model proposed by Dahn et al ${ }^{[27]}$. These observations explain the high ASA value for the material treated at $950^{\circ} \mathrm{C}$ and its decrease for higher temperatures: lower the structural organization higher the ASA. For samples annealed at $\mathrm{T} \geq$ 
$2000^{\circ} \mathrm{C}$ (Figure $2 \mathrm{f}-\mathrm{h}$ ) the graphene domains tend to orient in the basal plane as deduced from TEM images which shows that they consists of packing of 3 to 20 parallel graphene layers. This structural rearrangement results in the creation of mesopores whose importance with respect to the capturing of $\mathrm{Na}^{+}$ion will be discussed latter. Such a growing and orientation trend of the graphene domains increases with increasing further the heating temperature to $2800^{\circ} \mathrm{C}$. The graphitization improvement under high temperature annealing is also confirmed by selected area electron diffraction as shown in the inset of Fig.2 (a),(c), (f) and (h). The diffraction rings are clearly observed in CNF-2200 and CNF-2800, but not in CNF-650 and CNF-1250 due to their less ordered structure. Nevertheless, we are still remaining far away from a dull graphitization, the reason why PAN derivated carbon belongs to the hard carbon family.
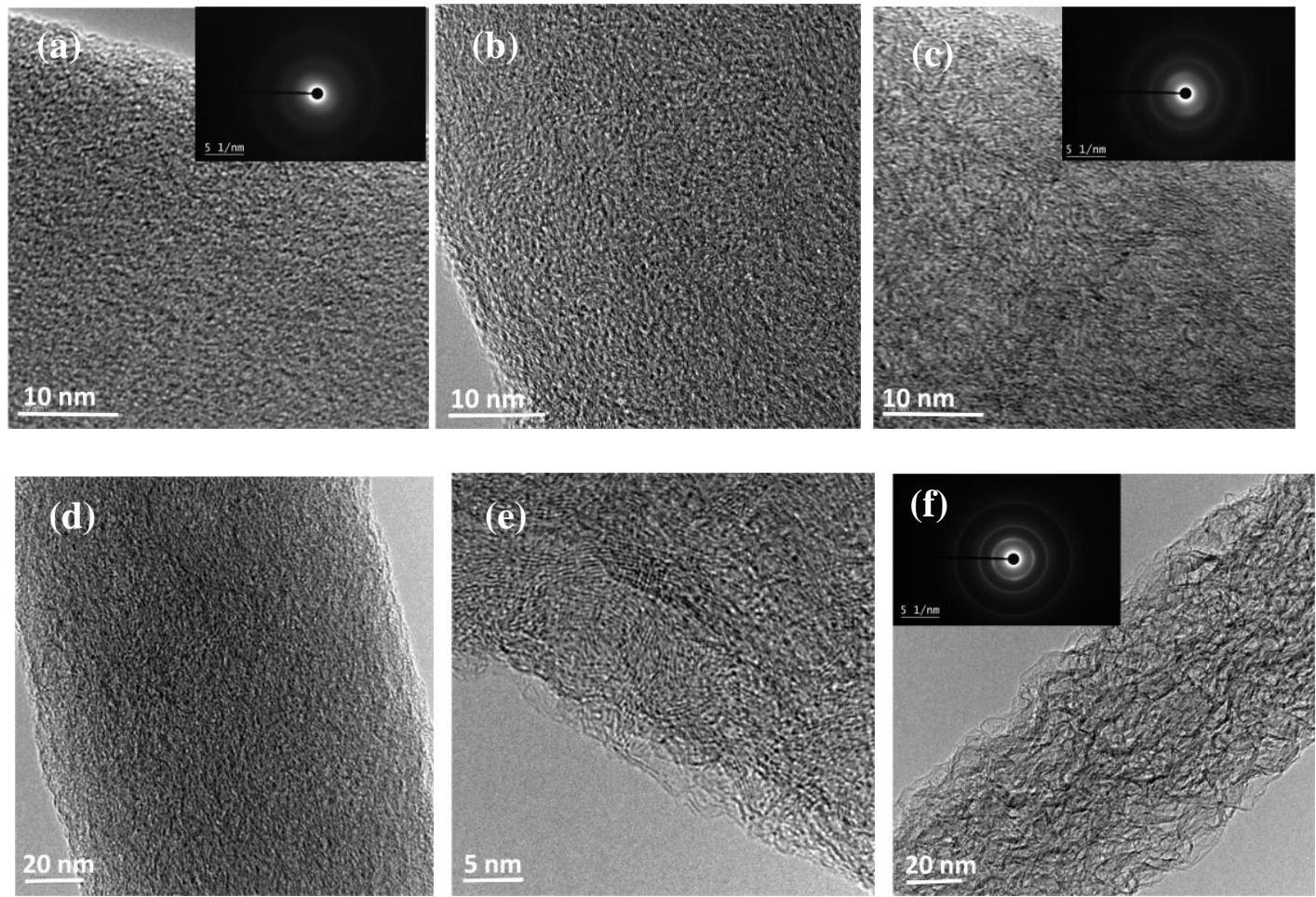

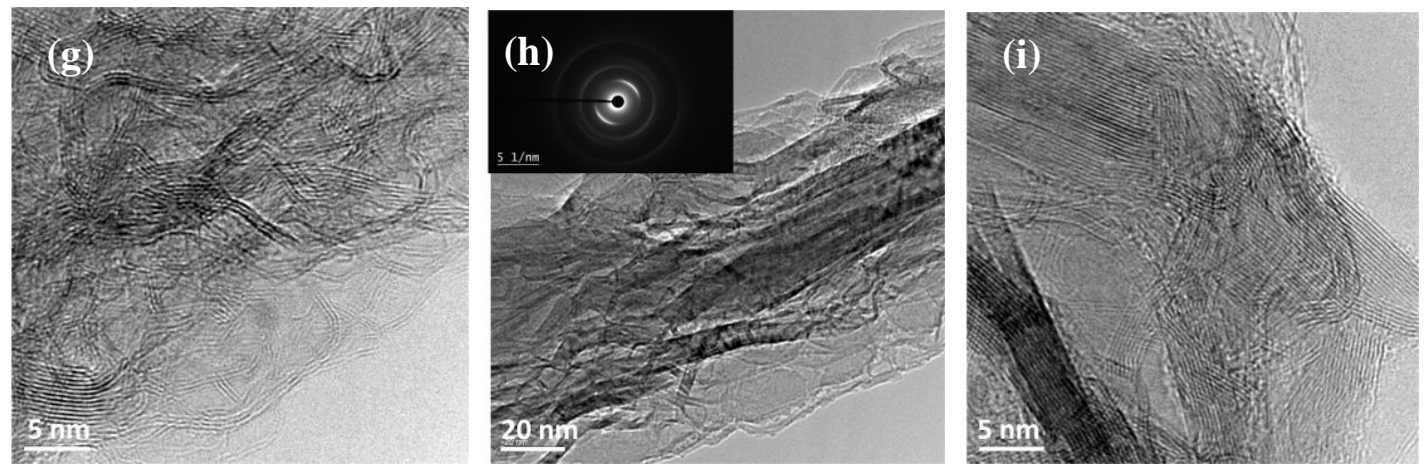

Figure 2 TEM images of (a) CNF-650 (b) CNF-950 (c) CNF-1250 (d)(e) CNF-1550 (f)(g) CNF-2200 and (h)(i) CNF-2800. The insets of (a)(c)(f)(h) show the selected area electron diffraction of corresponding samples.

In parallel to microscopy, XRD patterns (Figure 3a) reveal the existence of a wide (002) peak for CNFs carbonized at below 1000 degree which is indicative of structural disordering in agreement with the microscopy. The intensity of (002) peak improves when the carbonization temperature increases, but it remains broad till up to $1550{ }^{\circ} \mathrm{C}$. A further increase of carbonization temperature above $2000^{\circ} \mathrm{C}$ leads to a sharpening of the (002) graphitic that is reminiscent of an increase in the sample state of graphitization. To quantify these effects we further exploited the collected XRD patterns using the Bragg's law and Sherrer's formula. With increasing the carbonization temperature (Figure $3 b$ ) the d-spacing decreases by about $\sim 5 \%$ to reach a value of $0.343 \mathrm{~nm}$ at $2800^{\circ} \mathrm{C}$, which is close to that of graphite $(0.335 \mathrm{~nm})$, while the crystallite size increases from 0.4 at $650^{\circ} \mathrm{C}$ to about $6 \mathrm{~nm}$ at $2800^{\circ} \mathrm{C}$. This result may partly explain why similar ASA values are obtained for the CNFs as some graphite materials. In addition, the graphitization enhancement with temperature was also proven by Raman spectra (Figure S4), where a prominent G' band peak appears when the temperature reaches $2000^{\circ} \mathrm{C}$. Nevertheless, the $\mathrm{D}$ band peak is still intense even after carbonization at $2800^{\circ} \mathrm{C}$, indicating the presence of defects and/or pores ${ }^{[28]}$. 
(a)
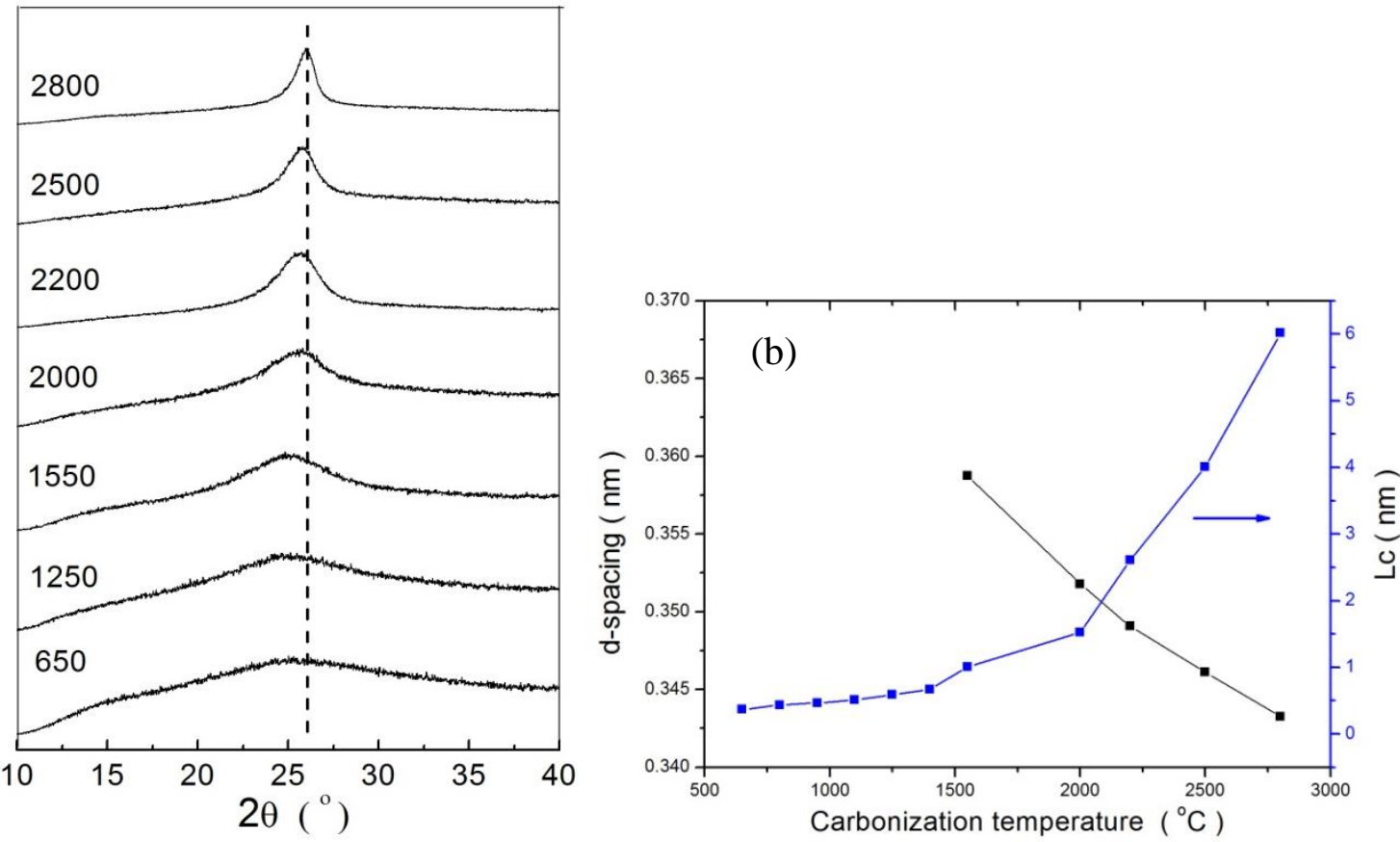

Figure 3 (a) XRD spectra and (b) derived d-spacing and crystalline size (Lc) as function of carbonization temperature

Insights on the textural features of CNFs were assessed by nitrogen and carbon dioxide adsorption. The nitrogen adsorption/desorption isotherms presented in Figure 4a exhibit a type II-shape for all CNFs materials specific to materials having low porosity. The BET surface area is similar for all materials $\left(\sim 20 \mathrm{~m}^{2} / \mathrm{g}\right)$, no matter the carbonization temperature, while the total pore volume tends to increase for high temperature annealed CNFs (Table 1). For sake of completeness we also determined the textural properties by $\mathrm{CO}_{2}$ adsorption. The $\mathrm{CO}_{2}$ adsorption isotherms (Figure S5) show a significant decrease in the adsorbed volume with the increase of the temperature between 650 and $950^{\circ} \mathrm{C}$. For higher temperatures $\left(1100-2800^{\circ} \mathrm{C}\right)$ the adsorbed volume is similar between the materials. If we compare the specific surface area and the total pore volume of $\mathrm{CO}_{2}$ with $\mathrm{N}_{2}$ (Table 1) it can be seen that for $\mathrm{CO}_{2}$ the values are about 5 to 10 times higher for low thermal treated CNFs $\left(650-950^{\circ} \mathrm{C}\right)$. For higher temperatures, the $\mathrm{CO}_{2}$ specific surface area becomes similar to the nitrogen one. This observation suggests 
the presence of ultramicropores for CNFs treated bellow $950^{\circ} \mathrm{C}$. Compared with $\mathrm{N}_{2}$ it is well known that $\mathrm{CO}_{2}$ is able to access better the narrow pores (ultramicropores) due to the enhanced diffusion, thus higher $\mathrm{CO}_{2}$ may be adsorbed. It must be recall that these materials contains high amounts of nitrogen and oxygen functionalities, which may influence the $\mathrm{CO}_{2}$ adsorption behaviour due to the presence of a quadrupole moment. However, this aspect remain still controversial in the literature. ${ }^{[29,30]}$ In addition, the DFT pore size distribution (Figure 4b) show different pore size depending on the annealing temperature. For low temperatures $\left(650-950^{\circ} \mathrm{C}\right)$ only micropores with size of about $1.2 \mathrm{~nm}$ are seen, while for higher temperatures small mesopores $(3.2 \mathrm{~nm})$ are formed. The formation of mesopores for temperatures superior to $950^{\circ} \mathrm{C}$ is as well confirmed by $\mathrm{BJH}$ model (Figure S5a). We believe that the micropores to mesopore evolution of CNFs with temperature can be explained as follows. The micropores present at low temperature $\left(650^{\circ} \mathrm{C}\right)$ most likely due to the poor stacking of C-C aromatic structures. The presence of functional groups are progressively disappear with increasing the carbonization temperature at the expense of graphene layers growth through which part of C atoms are expelled via the evolvement of $\mathrm{CO}_{x}$ and $\mathrm{HCN}$ to leave mesopores behind (as sustained TPD-MS and mass loss with the temperature). Moreover, the rotation of graphene layers with increasing temperature, as deduced from TEM measurements, could also in addition participate to the formation of mesopores.

Table 1 Textural properties of CNFs determined by $\mathrm{N}_{2}$ and $\mathrm{CO}_{2}$ adsorption.

\begin{tabular}{llllllll}
\hline Materials & $\begin{array}{l}\text { CNF- } \\
\mathbf{6 5 0}\end{array}$ & $\begin{array}{l}\text { CNF- } \\
\mathbf{8 0 0}\end{array}$ & $\begin{array}{l}\text { CNF- } \\
\mathbf{9 5 0}\end{array}$ & $\begin{array}{l}\text { CNF- } \\
\mathbf{1 1 0 0}\end{array}$ & $\begin{array}{l}\text { CNF- } \\
\mathbf{1 2 5 0}\end{array}$ & $\begin{array}{l}\text { CNF- } \\
\mathbf{2 2 0 0}\end{array}$ & $\begin{array}{l}\text { CNF- } \\
\mathbf{2 8 0 0}\end{array}$ \\
\hline $\begin{array}{l}\text { SSA N2 } \\
\left(\mathbf{m}^{2} / \mathbf{g}\right)\end{array}$ & 25 & 18 & 12 & 24 & 20 & 21 & 20 \\
$\begin{array}{l}\mathbf{S S A ~ C O} \\
\left(\mathbf{m}^{2} / \mathbf{g}\right)\end{array}$ & 226 & 197 & 67 & 24 & 20 & - & - \\
$\begin{array}{l}\mathbf{V t ~ N}_{2} \\
\left(\mathbf{c m}^{3} / \mathbf{g}\right)\end{array}$ & 0.026 & 0.022 & 0.015 & 0.033 & 0.028 & 0.040 & 0.037 \\
$\begin{array}{l}\mathbf{V t ~ C O}_{2} \\
\left(\mathbf{c m}^{3} / \mathbf{g}\right)\end{array}$ & 0.13 & 0.11 & 0.038 & 0.0058 & 0.0037 & - & - \\
\hline
\end{tabular}




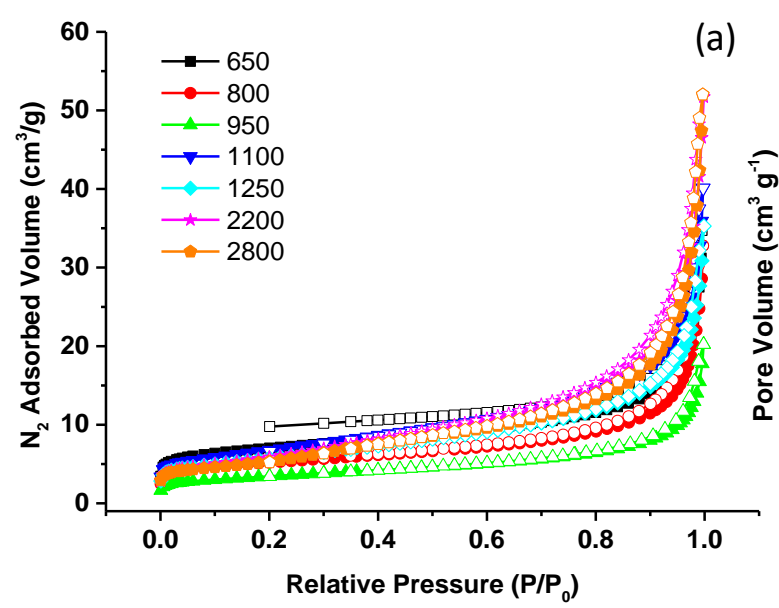

Figure 4 (a) $\mathrm{N}_{2}$ adsorption-desorption isotherms

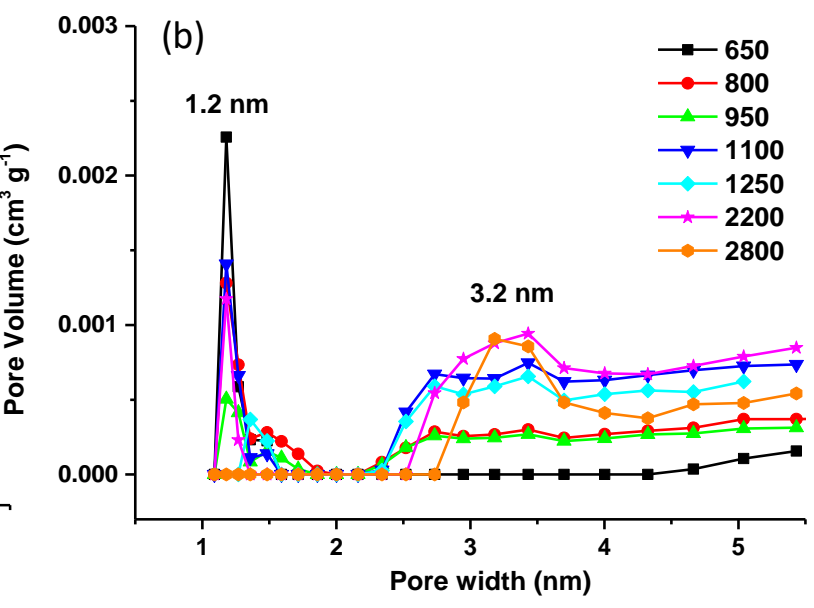

(b) DFT pore size distribution of CNFs carbonized at various temperatures.

So overall, based on all these analysis techniques we can deduce that CNFs undergo during carbonization up to $2800^{\circ} \mathrm{C}$ a three stages process enlisting subsequently i) the elimination of heteroatoms $\left(650-950{ }^{\circ} \mathrm{C}\right)$ and ultramicropores; II) the growth of graphene domains (1000$2000{ }^{\circ} \mathrm{C}$ ) and III) the graphitization $\left(>2000{ }^{\circ} \mathrm{C}\right.$ ) with the formation of small mesopores. At this stage a legitimate question deals with the importance of such carbonization sequences on the electrochemical properties of the resulting CNFs. Thus, the CNF films were punched into disks for using as electrodes in coin cells to evaluate their $\mathrm{Na}$ storage performance. The results are presented in Figure 5 by grouping the samples according to the three domains of temperatures defined above I, II, and III.

For stage I CNFs the voltage profiles show initially a pseudo plateau followed by a monotonous decrease of the voltage to $0 \mathrm{~V}$ with therefore a large irreversibility between the first discharge and first charge so that the total sustainable reversible capacity is limited 200 $\mathrm{mAh} / \mathrm{g}$. The high irreversible capacity can be ascribed to the disordered nature of the carbon as determined by XRD and TEM analysis. Note that $50 \%$ of this charge capacity in CNF-650 is obtained at voltages greater than $1 \mathrm{~V}$, due most likely to the high content of heteroatoms $(17.9 \% \mathrm{~N}$ and $10.6 \% \mathrm{O})$ in the samples in agreement with a previous study which has reported 
similar voltage profiles for $\mathrm{N}$ doped $\mathrm{CNFs}{ }^{[31]}$. Moreover, the decrease of the high voltage charge capacity contribution with increasing temperature (from $650^{\circ} \mathrm{C}$ to $950^{\circ} \mathrm{C}$ see arrows Figure 5a) does not come as a surprise since we have shown by XPS and TPD that the heteroatoms are progressively eliminated as the temperature is increased. A short low plateau at around $0.1 \mathrm{~V}$ pop-out in CNF-950, leading to the slightly higher capacity of CNF-950 than CNF-800 although the latter has higher capacity at above $1 \mathrm{~V}$. The capacity at around $0.1 \mathrm{~V}$ is related to the presence of tiny graphene layers spotted by TEM measurements (Fig. 2a) with the corresponding Na storage mechanism explained as follows.

For CNFs pertaining to the stage II temperature domain $(1100-1550)$, the voltage profile can be divided into two regions, i.e., sloping region between 1-0.1 V and a flat plateau region at $\sim 0.1 \mathrm{~V}$ that could remind alkali intercalation in graphite-type materials. Although $\mathrm{Na}$ interaction into graphite is not possible in carbonate electrolytes, it is worth mentioning here that recent studies have proposed that intercalation of $\mathrm{Na}^{+}$in graphene domains showing large d-spacing ${ }^{[14,32]}$ to account for the low voltage plateau ${ }^{[14]}$. This is in contrast with Dahn's early work in which the low voltage plateau is ascribed to nanopore filling ${ }^{[12]}$.

As an attempt to distinguish between these two possibilities, we electrochemically test CNFs treated at $\mathrm{T}>2000^{\circ} \mathrm{C}$ which are characterized by a high degree of graphitization. The first discharge curves show a initial plateau corresponding to SEI formation and afterwards a long plateau showing a reversible capacity of $\sim 200 \mathrm{mAh} / \mathrm{g}$ which maintain at $173 \mathrm{mAh} / \mathrm{g}$ after 50 cycles. Surprisingly, from the second cycle onwards, the two sloping and constant voltage regions present in stage II samples have merged into a single voltage plateau in stage III samples. It should be recalled that the materials prepared in this temperature interval present a high degree of graphitization, small mesopores and low active surface area (ASA $<0.5 \mathrm{~m}^{2} / \mathrm{g}$ ), hence low reactivity with the electrolyte. 

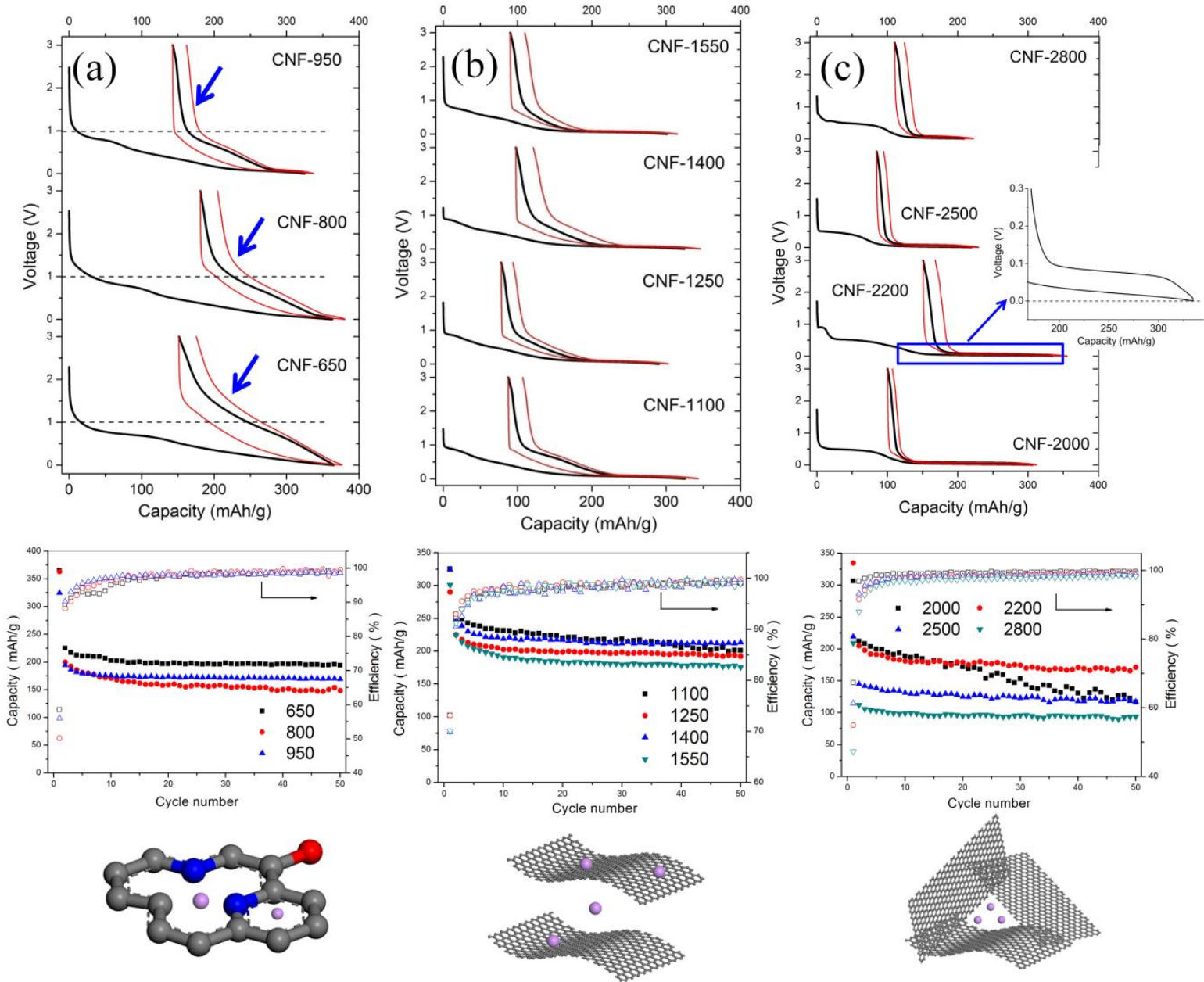

Figure 5 Voltage profiles (top), discharge capacity retention (middle) and schematic representation of Na ion storage mechanisms (bottom) in (a) Stage I, (b) Stage II and (c) Stage III CNFs.

To grasp further insight into any possible $\mathrm{Na}$ interaction, in-situ XRD measurements were conducted in a Swagelok type cell equipped with a beryllium window. While the cell being discharged to $0 \mathrm{~V}$, XRD patterns were collected at times refereed as circles in the voltage trace. Note that the collected XRD shows a broad background due to the electrolyte/separator contribution centered near $2 \theta=20^{\circ}$ which overlaps with the peak pertaining to carbon centered at $2 \theta=25.5$. To prevent any experimental artifacts, such background was systematically subtracted and the obtained XRD collection shown in Figure 6. No shift of the (002) peak was observed when the cell discharged to $0 \mathrm{~V}$. A similar experiment was conducted on the same 
sample vs. $\mathrm{Li}^{+} / \mathrm{Li}$ and in contrast to $\mathrm{Na}$ storage, the intercalation of $\mathrm{Li}$ between graphene layers is clearly observed as deduced by the left shift of (002) peak position during discharging together with its return back to the initial position upon charging (Figure S6). This highlights a different alkali uptake mechanism between both alkalis. The constancy of the d-spacing for Na-uptake in CNFs fiber implies that the low voltage plateau cannot be attributed (assigned) to $\mathrm{Na}$ intercalation.

Of course one still argue about the feasibility of having Na plating since the long voltage Na uptake plateau is close to $0 \mathrm{~V}$ vs. $\mathrm{Na} / \mathrm{Na}^{+}$. To eliminate this possibility the in-situ XRD cell was further discharged to below $0 \mathrm{~V}$ to purposely provoke Na plating. When the cell voltage approaches $-0.015 \mathrm{~V}$, the voltage trace shows a "V" shape characteristic indicative of the $\mathrm{Na}$ nucleation-growth process as further confirmed by the in-situ collected XRD patterns which show the progressive emergence of a small peak near $2 \theta=29^{\circ}$ corresponding to Na metal (Figure 6 and Figure S7). From such experiments we can unambiguously conclude that the low voltage plateau is neither due to $\mathrm{Na}$ intercalation nor Na plating. Note therefore that the capacity of the low voltage plateau become the most prominent only for samples treated at above 1000 ${ }^{\circ} \mathrm{C}$ which contains greater amounts of mesopores, hence in good agreement with the nanopore filling model ${ }^{[33]}$. The mesopores are partly removed when the temperature increases to above $2200{ }^{\circ} \mathrm{C}$ as a result of the further orientation of the graphene layers in the basal plane (Fig.2), which leads to the decrease in the capacity of CNF-2500 and CNF-2800.

A comparison between Stage II and Stage III CNFs shows that the sloping region almost disappears once the graphene sheets become parallels with smaller d-spacing. This implies that the sloping region is related to the $\mathrm{Na}$ storage in isolated or randomly oriented graphene layers. In-situ XRD does not show a clear shift of the (002) peak during discharging for stage II CNFs, probably due to adsorption of $\mathrm{Na}$ ions on the surface of graphene sheets instead of intercalation (Figure S8). It should be noted, however, the possibility of $\mathrm{Na}$ intercalation cannot be fully 
excluded in stage II CNFs because of the broadness of (002) peak which renders unreliable the detection of minors shift positions. This is one of the reason why the Na storage mechanism in less ordered carbon treated under this temperature range remains controversial $[\mathrm{xx}]$, requiring further investigations among which Na NMR could be quite useful. A little amount of isolated graphene sheets is-remained in stage III CNFs, giving rise to the small capacity between 0.1 and $1 \mathrm{~V}$.

So in light of the aforementioned results, the Na ion storage mechanism in CNFs enlists three different steps, depending upon their microstructure, composition and texture. They consist in i) the uptake of $\mathrm{Na}^{+}$by defect sites created by heteroatoms (mainly by $N$ as $O$ will lead to higher potentials), 2) the Na adsorption on disordered isolated graphene sheets resulting in a sloping region between $1 \mathrm{~V}-0.1 \mathrm{~V}$ and iii) in the mesopore filling that occurs at $\sim 0.1 \mathrm{~V}$ (Figure 5).

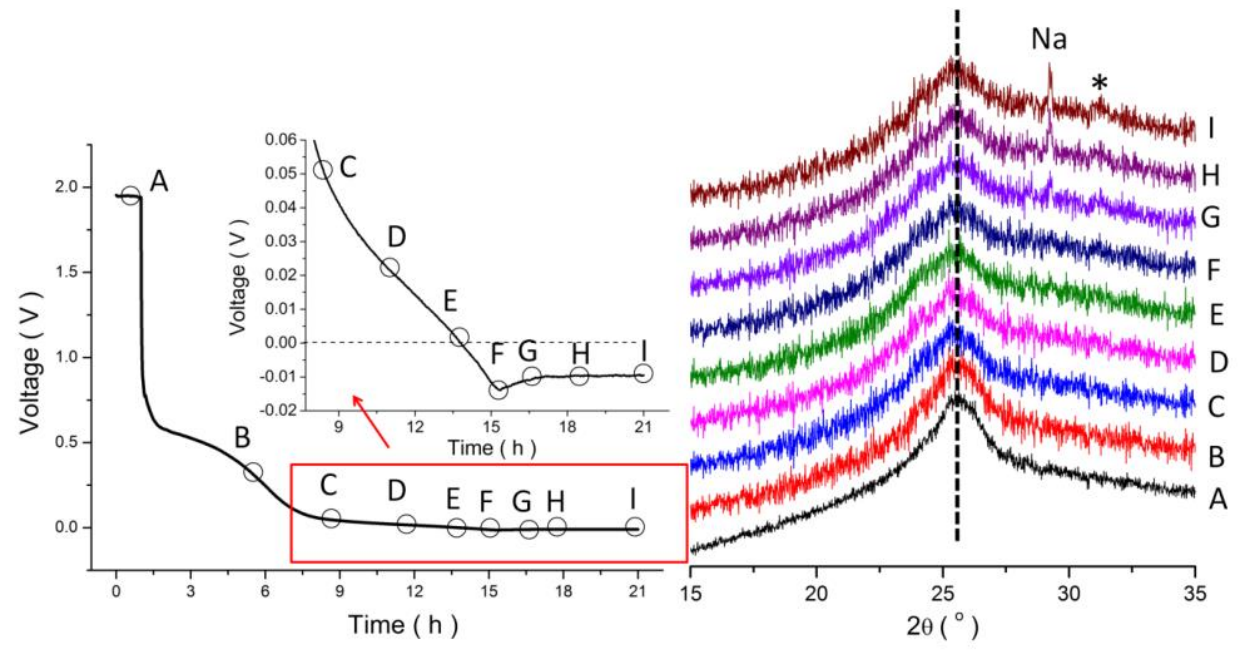

Figure 6 X-ray diffraction pattern recorded in-situ on the first discharge of CNF-2200, the cell was discharged at a current density of $35 \mathrm{~mA} / \mathrm{g}$. The peak marked with $*$ is due to the side reaction with the electrolyte.

For sake of comparison, the electrochemical behavior of all CNFs samples was investigated in Li-ion cells and only the most relevant voltage composition profiles, within the context of the paper, are reported in Figure S9. Stage 1 samples show both a large hysteresis 
together with a sloping region alike what was found with sodium and this was explained using similar storage mechanisms ${ }^{[34,35]}$.Turning to stages II and III, we note a decrease in the hysteresis, but neither of them show the onset of a well pronounced plateau at low voltage as observed for sodium, further confirming a different $\mathrm{Li}$ and $\mathrm{Na}$ uptake mechanisms at low voltage, despite the fact that these materials are alike in terms of microstructures, defects and morphologies.

Stage III CNFs that possess a single plateau at low voltage having a $\sim 200 \mathrm{mAh} / \mathrm{g}$ capacity could be attractive anode materials for delivering a high output voltage when coupling with cathodes. For proof of concept, full $\mathrm{Na}$-ion $\mathrm{CNF} / \mathrm{Na}_{2} \mathrm{Fe}_{2}\left(\mathrm{SO}_{4}\right)_{3}$ cells were assembled using as negative electrode CNFs samples treated at $1400^{\circ} \mathrm{C}$ and $2200^{\circ} \mathrm{C}$ (Figure 7). The voltage profile of $\mathrm{Na}_{2} \mathrm{Fe}_{2}\left(\mathrm{SO}_{4}\right)_{3}$ that prepared according to the literature ${ }^{[36]}$ in half cell is shown in Figure S10. Both the cells deliver a stable capacity of $\sim 70 \mathrm{mAh} / \mathrm{g}$ (based on the weight of $\mathrm{Na}_{2} \mathrm{Fe}_{2}\left(\mathrm{SO}_{4}\right)_{3}$, suggesting electrospun CNFs could be potential anodes for Na-ion batteries. Efforts are made undertaken to prepare large badges at low cost; which is-should not represent an unsurmountable task $[\mathrm{xx}] . "$

providing that efforts are made to prepare large badges at low cost; which is not an unsurmountable task [xx]. The capacity of CNFs are normalized to compare the influence of CNF voltage profile on the full cell. It can be seen that without sloping region $\mathrm{Na}_{2} \mathrm{Fe}_{2}\left(\mathrm{SO}_{4}\right)_{3} / \mathrm{CNF}-2200$ cell has higher output voltage than $\mathrm{Na}_{2} \mathrm{Fe}_{2}\left(\mathrm{SO}_{4}\right)_{3} / \mathrm{CNF}-1400$, showing potential improvement in energy density. Furthermore, synthesis of mesoporous carbon has been well studied in carbon community, thereby opening a wide window on synthesis high capacity carbon anode material through optimizing the porous and graphitic structure. 


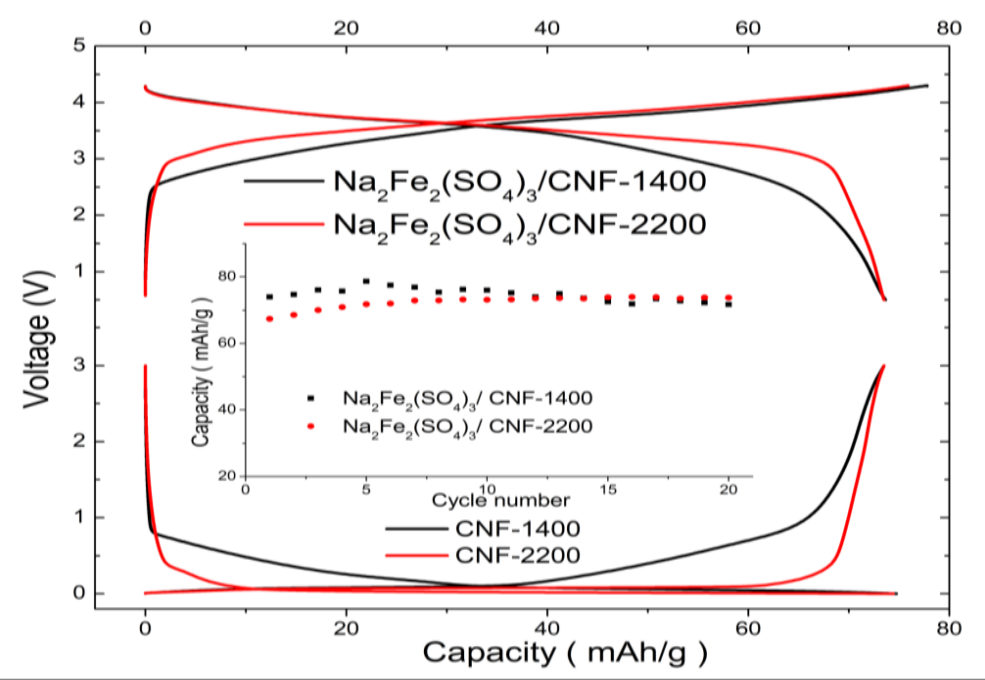

Figure 7 Electrochemical performance of full cells using $\mathrm{Na}_{2} \mathrm{Fe}_{2}\left(\mathrm{SO}_{4}\right)_{3}$ and CNFs as cathode and anode, respectively. The capacity of CNFs is normalized to compare their voltage profiles and influence in the full cell.

\section{Conclusions}

We have reported the preparation of CNFs from carbonization of electrospun PAN fibers and shown that their electrochemical performances towards $\mathrm{Na}$ strongly depend upon their characteristics induced by carbonization temperature. Using combined TEM, TPD-MS, XRD and adsorption techniques, we demonstrate that the materials present distinct textural, structural, and surface chemistry characteristics depending on the carbonization process. Low temperature made CNFs contain copious amounts of $\mathrm{O}$ and $\mathrm{N}$ heteroatoms, high disordered structure and high amounts of ultramicropores. Carbonization at $\mathrm{T}>1000^{\circ} \mathrm{C}$ gradually remove the heteroatoms and increases the ordered structure as well as the mesoporous volume. We find for temperatures of above $2000{ }^{\circ} \mathrm{C}$ the emergence of high density of graphite-type domains consisting of numerous pores surrounded by graphitic layers. Among the most pleasant result is the appearance of a low and single voltage plateau at $\sim 0.1 \mathrm{~V}$ which displays a reversible and sustained capacity close to $200 \mathrm{mAh} / \mathrm{g}$. While such low single voltage plateau is common for 
Li insertion in graphite, it is to our knowledge the first time that it has been observed for $\mathrm{Na}$ as well. We demonstrated here that this plateau is nested in the filling of the CNFs nanopores by $\mathrm{Na}^{+}$ions. Application-wise, we show the beneficial aspects of CNFs made by a scalable process, via the assembling of full $\mathrm{CNF} / \mathrm{Na}_{2} \mathrm{Fe}_{2}\left(\mathrm{SO}_{4}\right)_{3}$, which show better energy density. Obvious optimizations of this work range for means to i) design carbonaceous materials at lower temperatures for sustainable reasons while preserving similar performances, and ii) to eliminate their large irreversible capacities so that such electrodes could be used in Na-ion commercial cells. The above aspects are being explored to further exploit the right balance between porous and graphitic structure for elaborating electrochemically optimized carbons for the Na-ion technology.

\section{Experimental Section}

CNFs Preparation: CNF films are produced by electrospinning using PAN (Sigma, Mw of 150,000) as precursor. 6wt.\% PAN was dissolved in N-dimethylformamide and was stretched into fiber shape under a high voltage of $18 \mathrm{kV}$. The feed rate of PAN solution was $3.0 \mathrm{ml} / \mathrm{h}$ using a needle of diameter $1.2 \mathrm{~mm}$. A PAN fiber film was peeled off from Al plate collector, and stabilized at $250{ }^{\circ} \mathrm{C}$ for $3 \mathrm{~h}$ in a muffle furnace so as to achieve a cyclic structure and hence avoid the melting of PAN during high temperature treatment ${ }^{[37]}$. It was then carbonized under Ar atmosphere for $1 \mathrm{~h}$ at various temperatures between 650 and $2800{ }^{\circ} \mathrm{C}$. The duration of treatment for temperature higher than $2000{ }^{\circ} \mathrm{C}$ was reduced to 20 min due to the furnace manufacturing limitation. The as obtained samples are denoted as CNF- $x$, where $x$ represents carbonization temperature.

Material Characterization: XRD of CNFs was conducted using a Bruker D8 diffractometer with a $\mathrm{Cu} \mathrm{K} \alpha$ radiation source. The morphologies was characterized by SEM (Philips, XL30) and TEM (JEOL 2010F). The material composition and surface chemistry 
were evaluated by several complementary techniques. The global composition was determined with a Thermo Electron EA112 elemental analyser instrument. The CNFs surface functionality was assessed by XPS with a VG ESCALAB 250 spectrometer using an Al K $\alpha$ monochromatic source $(15 \mathrm{kV}, 15 \mathrm{~mA})$ and a multi-detection analyzer, under $10^{-8} \mathrm{~Pa}$ residual pressure.

Bulk groups functionality of materials was analyzed by TPD-MS. The CNFs were heat-treated in vacuum up to $950^{\circ} \mathrm{C}$ and the evolved gases were monitored by a mass spectrometer priory calibrated using $\mathrm{N}_{2}, \mathrm{H}_{2}, \mathrm{CO}, \mathrm{CO}_{2}$ and $\mathrm{H}_{2} \mathrm{O}$. The total amount of each gas released was computed by time integration of the TPD curves. The ASA was determined by performing TPD-MS experiments on CNFs cleaned under vacuum at $950^{\circ} \mathrm{C}$ and subsequently exposed to di-oxygen chemisorption at $300^{\circ} \mathrm{C}$. More details about the procedure can be found in our previous works ${ }^{[25,26]}$.

The textural properties of the CNFs were determined from the study of the adsorption isotherms of $\mathrm{N}_{2}$ at $77 \mathrm{~K}$ and $\mathrm{CO}_{2}$ at $273 \mathrm{~K}$ using a Micromeritics ASAP 2020 instrument. Prior to the analysis the CNFs were pressed to reduce their volume and then out-gassed overnight under vacuum at $300^{\circ} \mathrm{C}$. The BET surface area $\left(S_{B E T}\right)$ was calculated in the relative pressure range of 0.05-0.3 for $\mathrm{N}_{2}$ adsorption. The total pore volume $V_{p}$ was obtained from the amount of $\mathrm{N}_{2}$ adsorbed at a relative pressure of 0.95 and 0.03 for $\mathrm{N}_{2}$ and $\mathrm{CO}_{2}$ adsorption, respectively. The pore size distribution was assessed by DFT model for slit pores more adapted for these materials $^{[38]}$, but also by BJH adsorption for comparison reasons.

Electrochemical tests: CNF films were punched into a circle with diameter of $11 \mathrm{~mm}$ and typical weight of $1 \mathrm{mg}$. It was used directly as electrodes in 2032 coin cells, where a $\mathrm{Na}$ metal was used as counter electrode. $1 \mathrm{M} \mathrm{NaClO}_{4}$ in ethyl carbonate (EC)/dimethyl carbonate (DMC) (1:1 by volume) and glass fiber (Whatman, GF/D) were employed as the electrolyte and separator, respectively. The cells were cycled between $0-3 \mathrm{~V}$ at a current density of 50 $\mathrm{mA} / \mathrm{g}$ in galvanostatic model using VMP system (Biologic S.A., Claix, France), taking around 
$8 \mathrm{~h}$ for one full cycle depending on the capacity.- Swagelok style cell with a beryllium window was fabricated for in-situ XRD measurements.

\section{Supporting Information}

Supporting Information is available from the Wiley Online Library or from the author.

\section{Acknowledgements}

The RS2E (Réseau sur le Stockage Electrochimique de l'Energie) network is acknowledged for the financial support of this work through the ANR project Storex (ANR-10-LABX-76-01).

The authors thank Marie-Paule Hirn, Samar Hajjar-Garreau, Georges Moussa and Jeseph Dentzer (IS2M) for the help provided with the CNFs characterization.

\section{References:}

[1] M. D. Slater, D. Kim, E. Lee, C. S. Johnson, Adv. Funct. Mater. 2013, 23, 947.

[2] D. Larcher, J. Tarascon, Nat. Chem. 2014, 7, DOI 10.1038/nchem.2085.

[3] N. Yabuuchi, M. Kajiyama, J. Iwatate, H. Nishikawa, S. Hitomi, R. Okuyama, R. Usui, Y. Yamada, S. Komaba, Nat. Mater. 2012, 11, 512.

[4] Y.-U. Park, D.-H. Seo, H. Kim, J. Kim, S. Lee, B. Kim, K. Kang, Adv. Funct. Mater. 2014, 24, 4603.

[5] A. Darwiche, C. Marino, M. T. Sougrati, B. Fraisse, L. Stievano, L. Monconduit, J. Am. Chem. Soc. 2012, 134, 20805.

[6] B. Jache, P. Adelhelm, Angew. Chemie - Int. Ed. 2014, 53,10169.

[7] D. A. Stevens, J. R. Dahn, J. Electrochem. Soc. 2000, 147, 1271.

[8] Y. X. Wang, S. L. Chou, H. K. Liu, S. X. Dou, Carbon 2013, 57, 202.

[9] M. Dahbi, N. Yabuuchi, K. Kubota, K. Tokiwa, S. Komaba, Phys. Chem. Chem. Phys. 2014, 16, 15007. 
[10] A. Ponrouch, A. R. Goñi, M. R. Palacín, Electrochem. commun. 2013, 27, 85.

[11] Z. Wang, L. Qie, L. Yuan, W. Zhang, X. Hu, Y. Huang, Carbon 2013, 55, 328.

[12] D. A. Stevens, J. R. Dahn, J. Electrochem. Soc. 2001, 148, A803.

[13] E. M. Lotfabad, J. Ding, K. Cui, A. Kohandehghan, W. P. Kalisvaart, M. Hazelton, D. Mitlin, ACS Nano 2014, 8, 7115.

[14] Y. Cao, L. Xiao, M. L. Sushko, W. Wang, B. Schwenzer, J. Xiao, Z. Nie, L. V. Saraf, Z. Yang, J. Liu, Nano Lett. 2012, 12, 3783.

[15] H. G. Wang, Z. Wu, F. L. Meng, D. L. Ma, X. L. Huang, L. M. Wang, X. B. Zhang, ChemSusChem 2013, 6, 56.

[16] B. Zhang, Z. Xu, Y. He, S. Abouali, M.A. Garakani, E.K. Heidari, F. Kang, J.K. Kim, Nano Energy 2014, 4, 88.

[17] B. Zhang, Y. Yu, Z. Huang, Y.-B. He, D. Jang, W.-S. Yoon, Y.-W. Mai, F. Kang, J.K. Kim, Energy Environ. Sci. 2012, 5, 9895.

[18] W. Li, L. Zeng, Z. Yang, L. Gu, J. Wang, X. Liu, J. Cheng, Y. Yu, Nanoscale 2014, 6, 693.

[19] L. Wu, X. Hu, J. Qian, F. Pei, F. Wu, R. Mao, X. Ai, H. Yang, Y. Cao, Energy Environ. Sci. 2014, 7, 323.

[20] G. Zhou, F. Li, H.-M. Cheng, Energy Environ. Sci. 2014, 7, 1307.

[21] M. Inagaki, Y. Yang, F. Kang, Adv. Mater. 2012, 24, 2547.

[22] J. Tascon, Novel carbon adsorbents, Elsevier, 2012, pp. 109-145

[23] C. M. Ghimbeu, R. Gadiou, J. Dentzer, L. Vidal, C. Vix-Guterl, Adsorption 2011, 17, 227.

[24] C. M. Ghimbeu, R. Gadiou, J. Dentzer, D. Schwartz, C. Vix-Guterl, Langmuir 2010, $26,18824$.

[25] P. Bernardo, J. Dentzer, R. Gadiou, W. Märkle, D. Goers, P. Novák, M. E. Spahr, C. Vix-Guterl, Carbon N. Y. 2011, 49, 4867.

[26] C. M. Ghimbeu, C. Decaux, P. Brender, M. Dahbi, D. Lemordant, E. RaymundoPiñero, M. Anouti, F. Béguin, C. Vix-Guterl, J. Electrochem. Soc. 2013, 160, A1907.

[27] T. Zheng, W. Xing, J. R. Dahn, Carbon N. Y. 1996, 34, 1501.

[28] A. C. Ferrari, J. C. Meyer, V. Scardaci, C. Casiraghi, M. Lazzeri, F. Mauri, S. Piscanec, D. Jiang, K. S. Novoselov, S. Roth, a. K. Geim, Phys. Rev. Lett. 2006, 97, 187401 . 
[29] S. Furmaniak, A. P. Terzyk, P. a Gauden, P. J. F. Harris, P. Kowalczyk, J. Phys.: Condens. Matter, 2010, 22, 085003.

[30] M. Sevilla, J. B. Parra, A. B. Fuertes, ACS Appl. Mater. Interfaces 2013, 5, 6360.

[31] L. Fu, K. Tang, K. Song, P. a van Aken, Y. Yu, J. Maier, Nanoscale 2014, 6, 1384.

[32] Y. Wen, K. He, Y. Zhu, F. Han, Y. Xu, I. Matsuda, Y. Ishii, J. Cumings, C. Wang, Nat. Commun. 2014, 5, 4033.

[33] D.A. Stevens, J. R. Dahn, J. Electrochem. Soc. 2000, 147, 4428.

[34] B. Zhang, Y. Yu, Z.-L. Xu, S. Abouali, M. Akbari, Y.-B. He, F. Kang, J.-K. Kim, Adv. Energy Mater. 2014, 4, 1301448.

[35] D. S. Su, R. Schlögl, ChemSusChem 2010, 3, 136.

[36] P. Barpanda, G. Oyama, S.-I. Nishimura, S.-C. Chung, A. Yamada, Nat. Commun. 2014, 5, 4358.

[37] M. S. a. Rahaman, A. F. Ismail, A. Mustafa, Polym. Degrad. Stab. 2007, 92, 1421.

[38] P. I. Ravikovitch, G. L. Haller, A. V. Neimark, Adv. Colloid Interface Sci. 1998, 7677, 203. 
A correlation between the microstructure and Na-ion storage behavior in hard carbon materials is established. A single low voltage plateau is observed in the carbon materials annealed at above $2000^{\circ} \mathrm{C}$. It is demonstrated via the assembly of a full cell the benefit of such single low voltage plateau for enhancing the energy density of Na-ion batteries.

Keyword: Na-ion battery, hard carbon, carbon nanofiber, microstructure

Biao Zhang, Camélia Matei Ghimbeu, Christel Laberty, Cathie Vix-Guterl and Jean-Marie Tarascon*

Correlation between microstructure and Na storage behavior in hard carbon

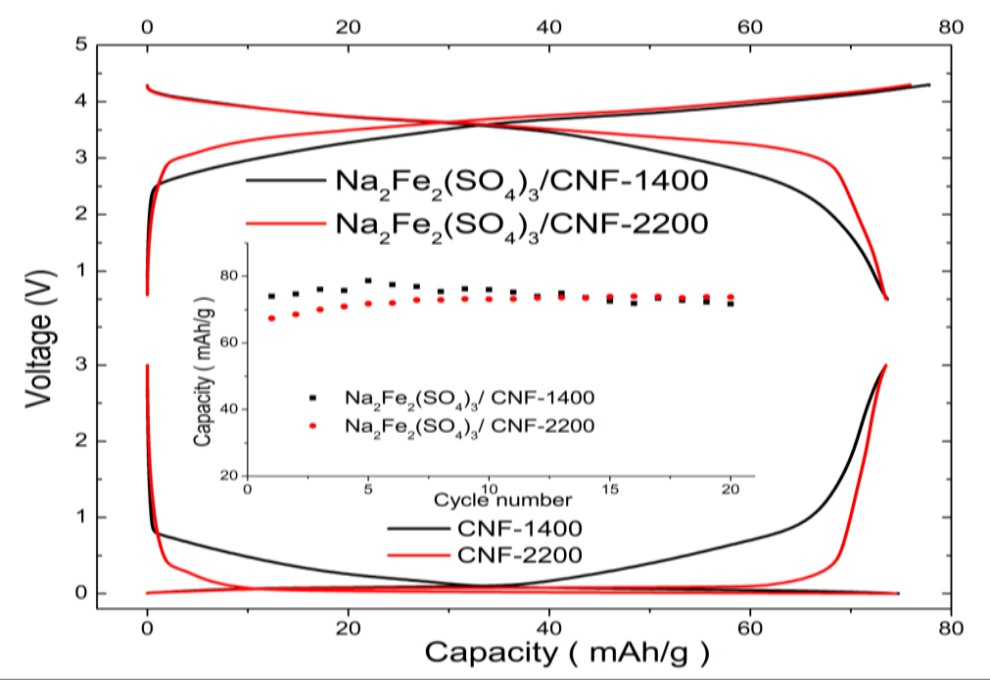


Supporting Information

\title{
Correlation between microstructure and Na storage behavior in hard carbon
}

\author{
Biao Zhang, Camélia Matei Ghimbeu, Christel Laberty, Cathie Vix-Guterl and Jean-Marie \\ Tarascon*
}

Dr. B. Zhang, Prof. J.M. Tarascon

FRE 3677 "Chimie du Solide et Energie", Collège de France, 11 Place Marcelin Berthelot, 75231 Paris Cedex 05, France.

Email: jean-marie.tarascon@college-de-france.fr

Dr. C.Matei Ghimbeu, Dr. C. Vix-Guterl

Institut de Science des Matériaux de Mulhouse (IS2M) - CNRS UMR 7361, France

Prof. C. Laberty

LCMCP, Université de Jussieu 75005, Paris, France

Dr. B. Zhang, Dr. C.Matei Ghimbeu, Prof. C. Laberty, Dr. C. Vix-Guterl, Prof. J.M. Tarascon

Réseau sur le Stockage Electrochimique de 1'Energie (RS2E), FR CNRS 3459, France 

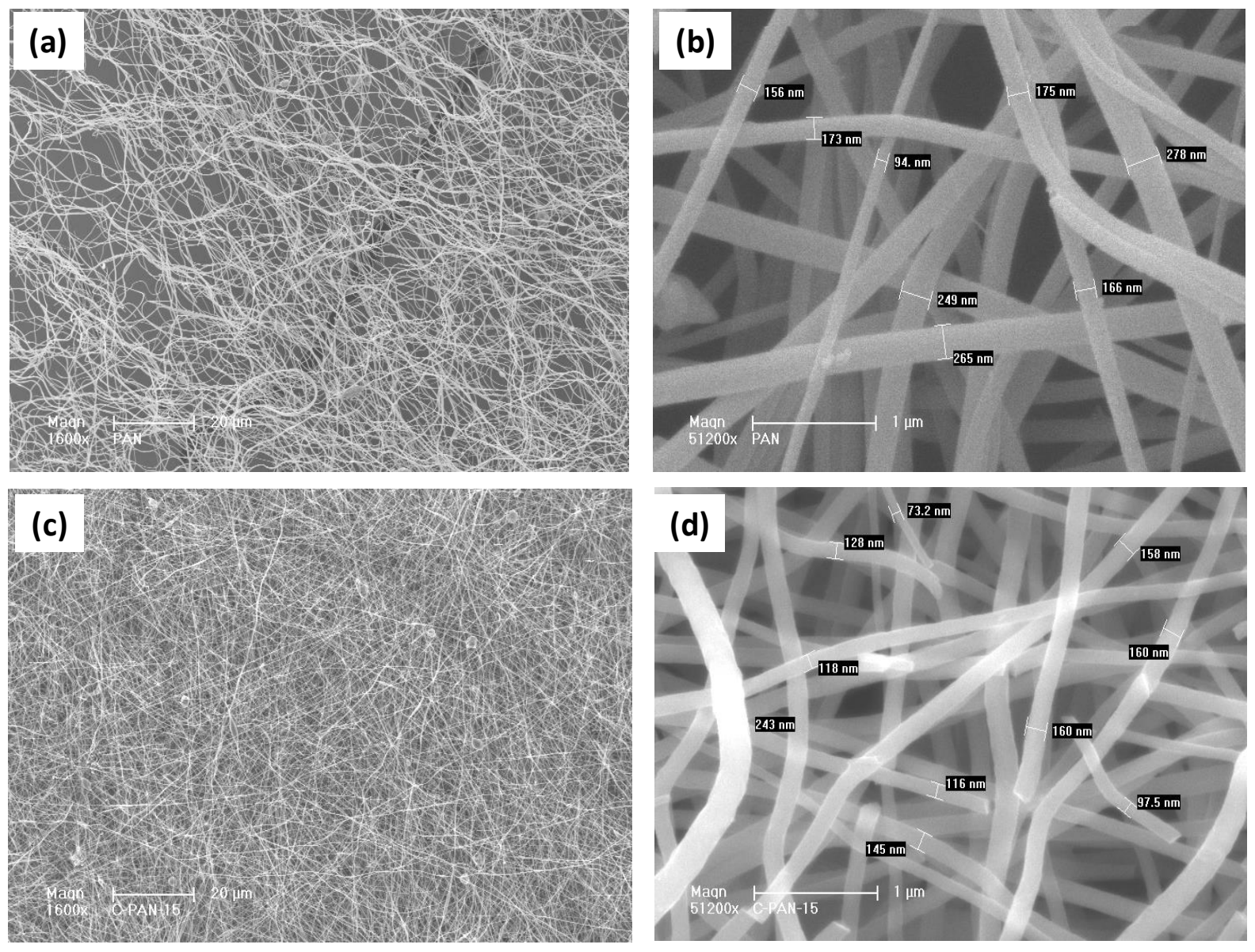

Figure S1 SEM images of (a)(b) PAN fibers and (c)(d) CNF-1550

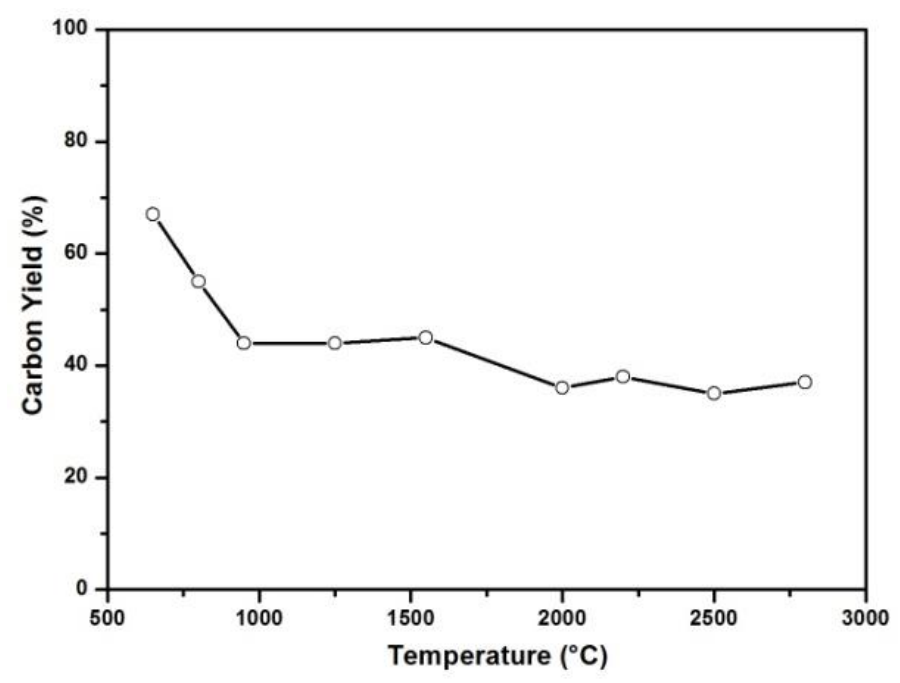

Figure S2 Carbon yield versus annealing temperature of PAN fibers 

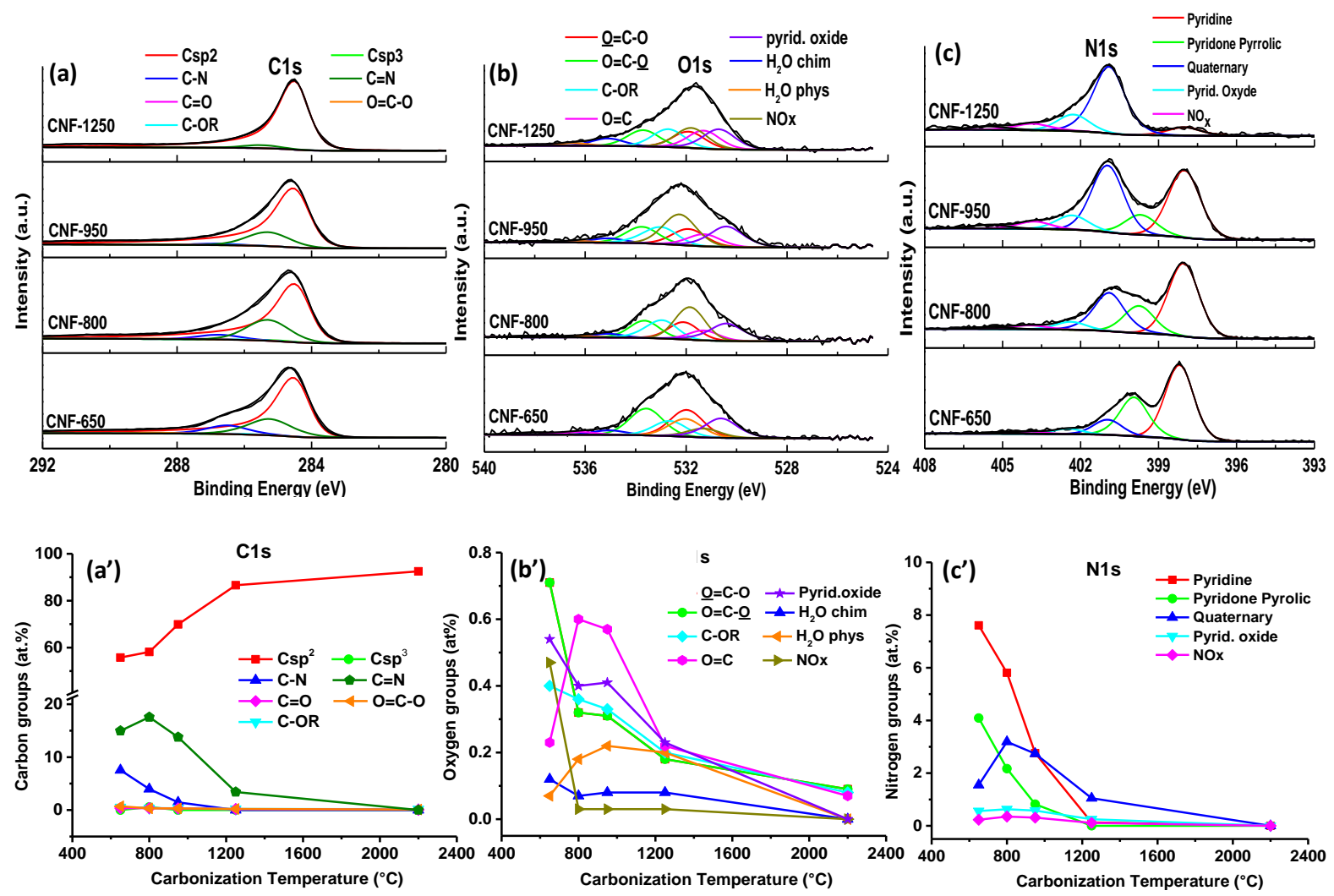

Figure S3 Evolution of $\mathrm{C}, \mathrm{O}$ and $\mathrm{N}$ groups with temperature (a', b', c') as determined using the deconvoluted XPS spectra $(\mathrm{a}, \mathrm{b}, \mathrm{c})$.

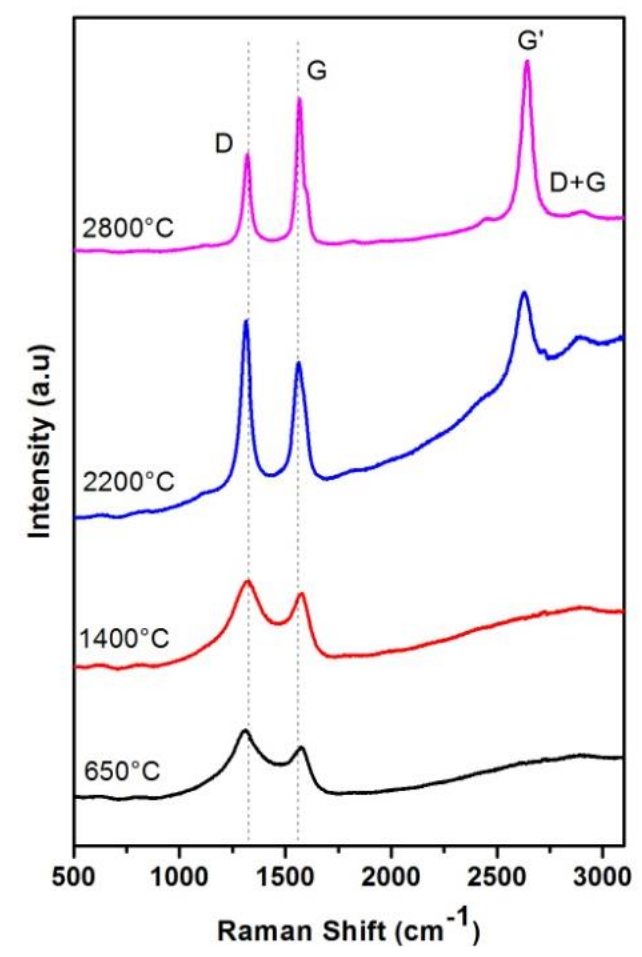

Figure S4 Raman spectra of CNFs carbonized at various temperatures. 

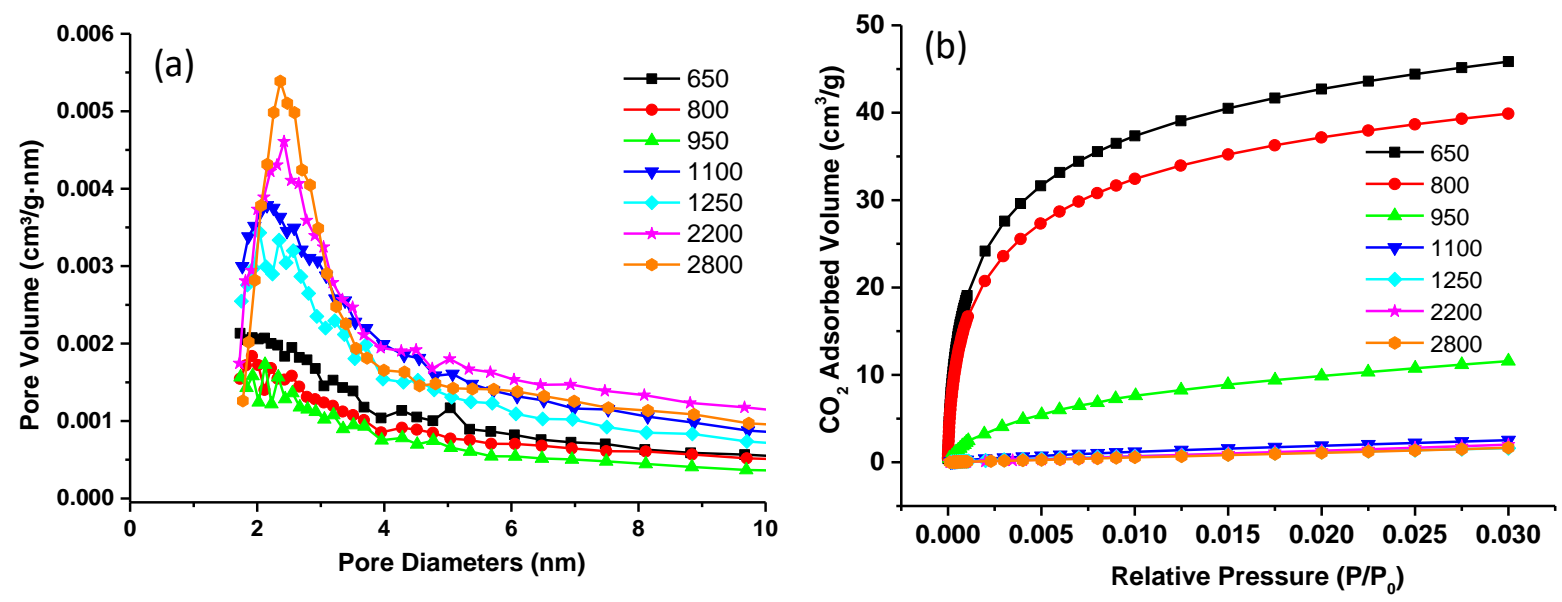

Figure S5 (a) $\mathrm{BJH}$ adsorption pores size distribution (b) $\mathrm{CO}_{2}$ adsorption isotherms of CNFs carbonized at various temperatures.
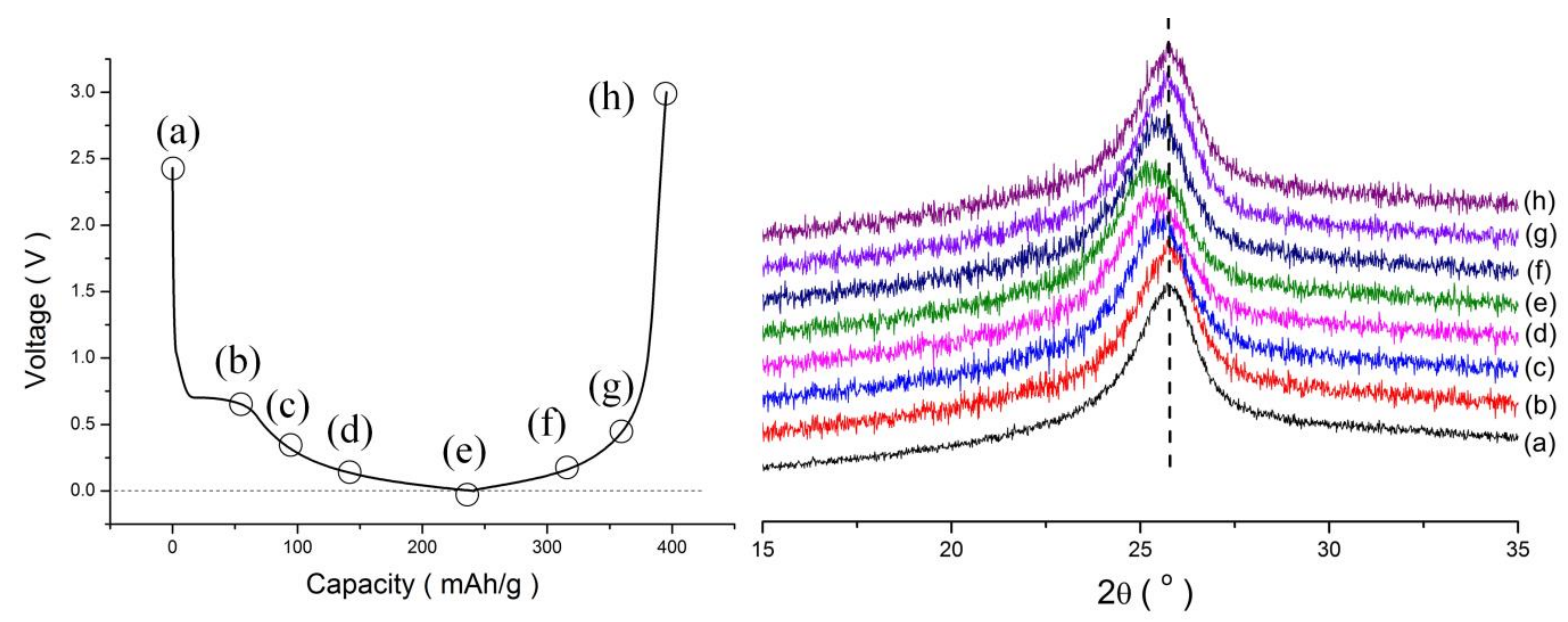

Figure S6 X-ray diffraction pattern recorded in-situ on the first discharge of CNF-2200 in Liion battery. 

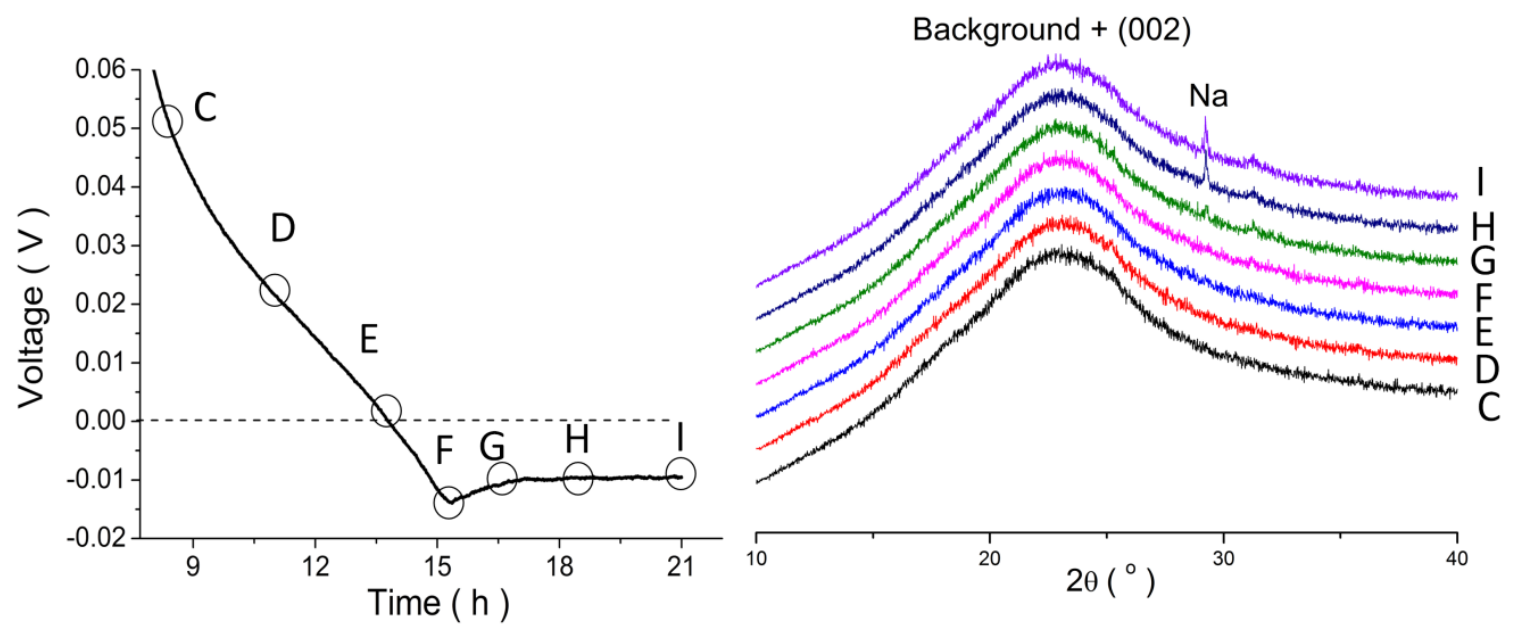

Figure S7 Selected XRD patterns recorded in-situ on the first discharge of CNF-2200 in Naion battery. The background of separator and electrolyte is not subtracted to clearly identify the $\mathrm{Na}$ peaks.
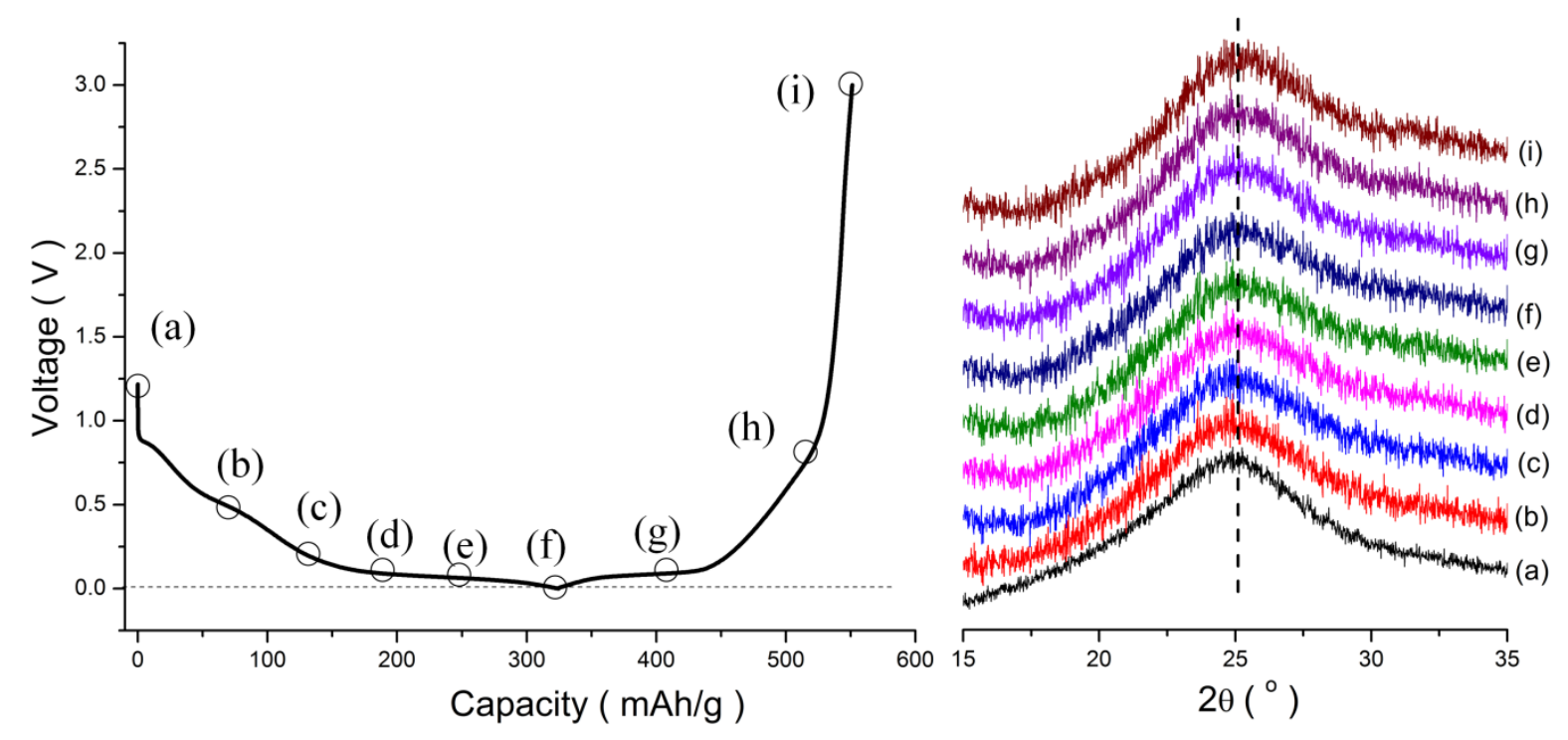

Figure S8 X-ray diffraction pattern recorded in-situ on the first discharge of CNF-1400 in Naion battery. 


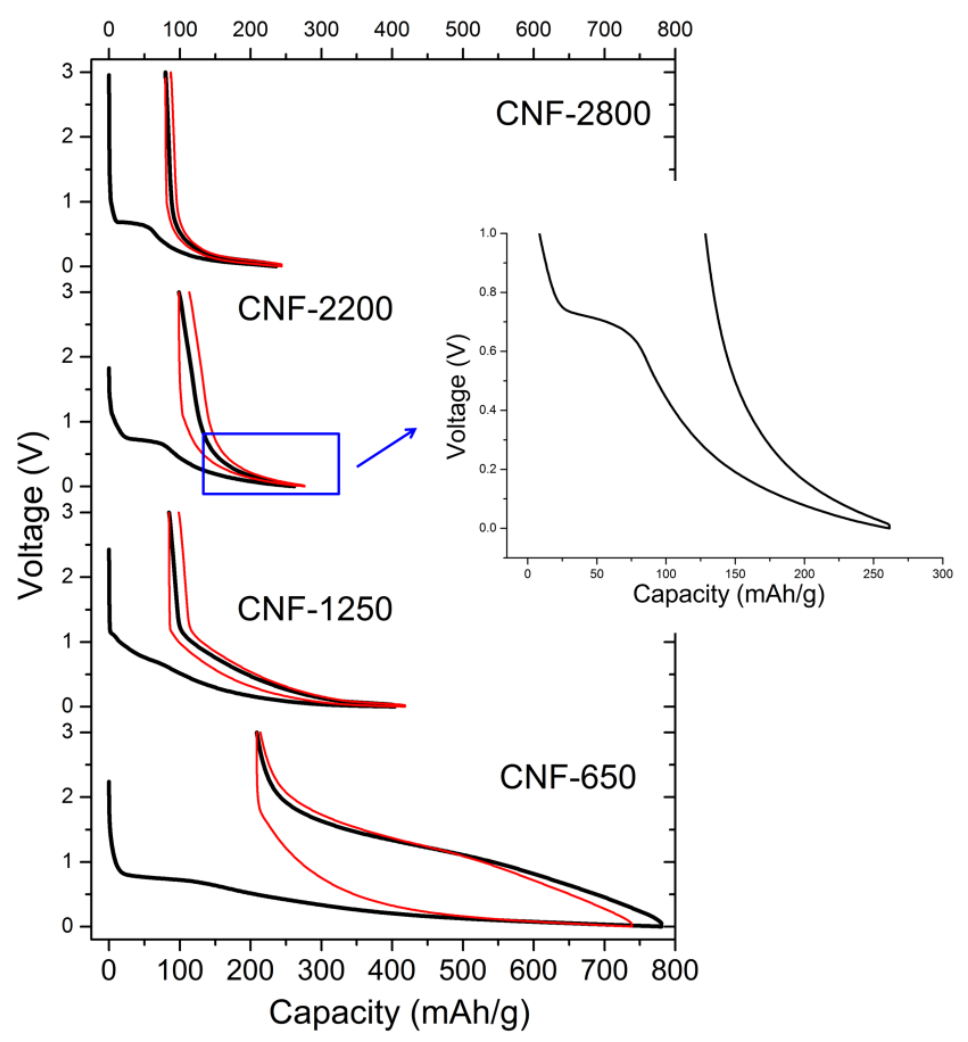

Figure S9 Voltage profiles of Li storage in CNFs. Electrolyte: $1 \mathrm{M} \mathrm{LiClO}_{4}$ in ethyl carbonate (EC)/dimethyl carbonate (DMC) (1:1 by volume).

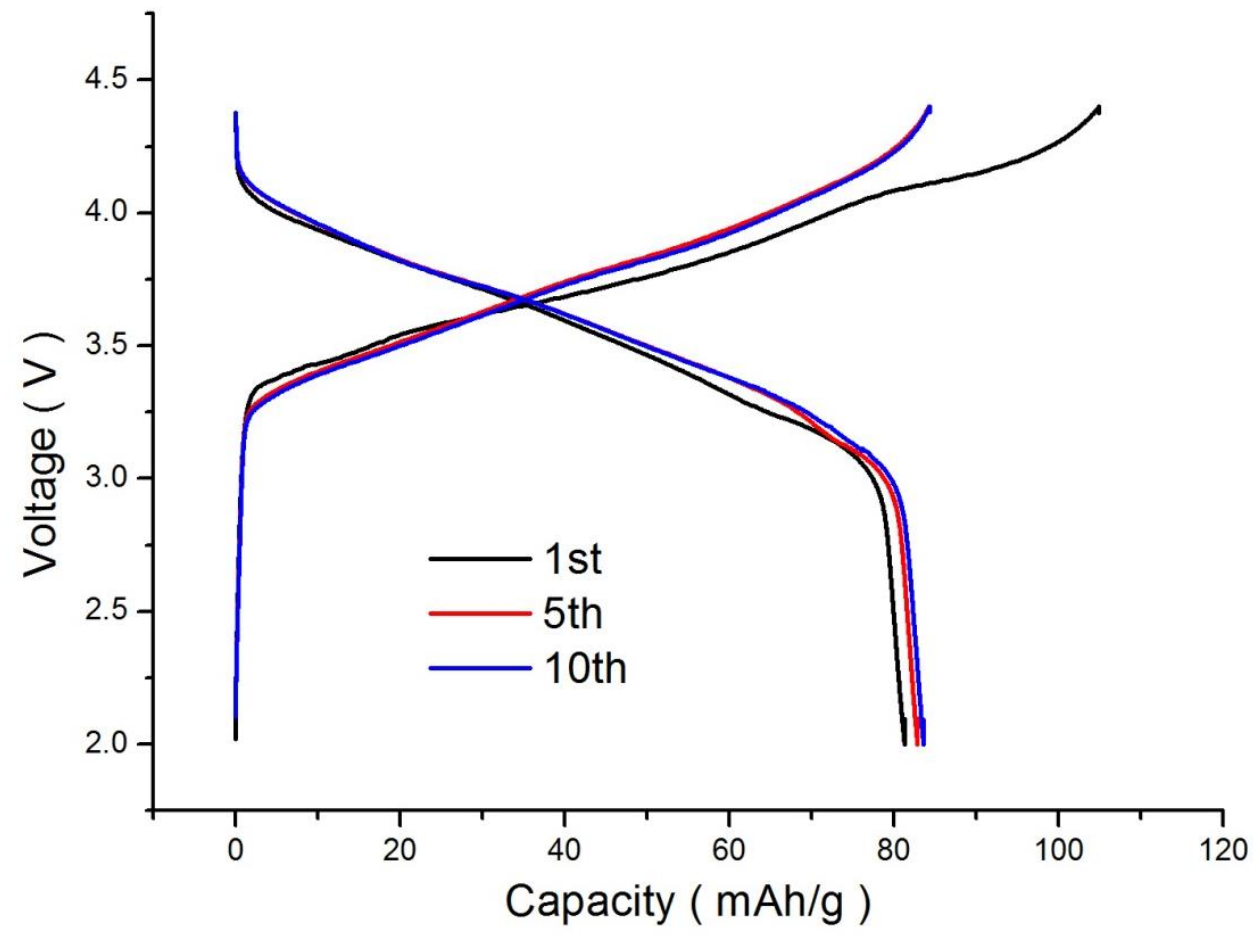

Figure $\mathrm{S} 10$ Voltage profiles of $\mathrm{Na}_{2} \mathrm{Fe}_{2}\left(\mathrm{SO}_{4}\right)_{3}$ in half cell with $\mathrm{Na}$ as a counter electrode. 